\title{
Kronieken
}

\section{Hoger beroep}

\section{Inleiding}

Het civiele hoger beroep staat in de belangstelling. ${ }^{1}$ Dat blijkt bijvoorbeeld uit het verschijnen van de 'Agenda voor de appelrechtspraak 2020' en van de bundel Hoger beroep: renovatie en innovatie, ${ }^{2}$ uit het aan laatstgenoemde bundel gewijde symposium, ${ }^{3}$ en uit de aan het grievenstelsel in hoger beroep gewijde najaarsvergadering van de Nederlandse Vereniging voor Procesrecht. ${ }^{4}$ Ook het in consultatie gebrachte, en inmiddels naar de Tweede Kamer gestuurde, 'Voorstel tot wijziging van het Wetboek van Burgerlijke Rechtsvordering in verband met vereenvoudiging en digitalisering van het procesrecht in hoger beroep en cassatie' heeft de aandacht weer op de procedure in hoger beroep gevestigd. 5

In de jurisprudentie van de Hoge Raad valt op dat veel arresten zijn gewezen over rolperikelen in hoger beroep: akte niet-dienen, schorsingen en het vragen van pleidooi. Andere thema's waren termijnoverschrijdingen, appellabiliteit (en de doorbreking van het rechtsmiddelenverbod), verzet en proceskosten. Daaraan wil ik in deze kroniek aandacht besteden. Daarbij zal ik relatief uitgebreid stilstaan bij de akte niet-dienen omdat zich daarmee in de praktijk regelmatig ongelukken blijken voor te doen. Verder kunnen ook het grievenstelsel, de devolutieve werking en de twee-conclusieregel niet onbesproken blijven; zonder dat zou een kroniek 'Hoger beroep' anno 2015 niet compleet zijn. Ook wil ik terugkomen op het terugwijzingsverbod; over de reikwijdte daarvan zijn sinds de vorige kroniek duidelijke arresten verschenen. Een ander belangrijk thema in hoger beroep, namelijk de positie van procespartijen, veranderingen in hoedanigheid of verkeerde aanduidingen, kan ik wel onbesproken laten. Ook daarover heeft de Hoge Raad interessante uitspraken gedaan, maar die zijn al voor het voetlicht gebracht in de recente kroniek 'Partijen' ${ }^{6}$

1. Dat zowel TCR 2014, afl. 3 als TCR 2014, afl. 4 met woorden van gelijke strekking opende, zal geen toeval zijn.

2. A. Hol \& J. Verburg (red.), Innoverende hoven. Agenda voor de appel rechtspraak 2020, Den Haag: Boom Juridische uitgevers 2014 P.H.P.H.M.C. van Kempen, C.J.M. Klaassen, R.J.N. Schlössels \& J.J. Dammingh (red.), Hoger beroep: renovatie en innovatie, Deventer: Kluwer 2014 .

3. Zie voor de bijdragen van E.M. Wesseling-van Gent en A. Hammerstein aan dit op 25 april 2014 gehouden symposium: TCR 2014, afl. 3, p. 66-75.

4. Zie voor een verslag van deze vergadering d.d. 12 december 2014: P.E. Ernste, Het grievenstelsel (een evaluatie: nodig/wenselijk, alternatieven?). Verslag van de najaarsvergadering 2014 van de Nederlandse Vereniging voor Procesrecht, TCR 2015, afl. 1, p. 31-40.

5. Zie <www.internetconsultatie.nl/hogerberoepkei>; Kamerstukken II 2014/15, 34138 .

6. B. Winters, Kroniek: partijen, TCR 2014, afl. 4, p. 119-127.

7. TCR 2013, afl. 1, p. 28-35.
In de vorige kroniek heb ik de ontwikkelingen tot en met december 2012 besproken. ${ }^{7}$ Deze kroniek beslaat de periode januari 2013 tot medio april 2015.

\section{Appeltermijn}

De Hoge Raad heeft herhaald dat aan beroepstermijnen strikt de hand moet worden gehouden. ${ }^{8}$ Rechtsmiddelentermijnen zijn van openbare orde en dienen door de rechter ambtshalve te worden toegepast. In het belang van een goede rechtspleging moet duidelijkheid bestaan over het tijdstip waarop een termijn voor het aanwenden van een rechtsmiddel aanvangt en eindigt. Op de strikte handhaving van de termijnen kan slechts onder bijzondere omstandigheden een uitzondering worden gemaakt, zoals in het geval van zogenoemde apparaatsfouten. ${ }^{9}$ Dat partijen ondanks een (geringe) termijnoverschrijding het hof hebben verzocht om de zaak toch ten gronde af te doen, rechtvaardigt niet dat een uitzondering wordt gemaakt op de strikte regels inzake rechtsmiddelentermijnen. Partijen kunnen daarvan niet afwijken, ook niet als zij het er samen over eens zijn. ${ }^{10}$

Ingevolge art. 358 lid 2 van het Wetboek van Burgerlijke Rechtsvordering $(\mathrm{Rv})$ moet in een verzoekschriftprocedure door een niet-verschenen belanghebbende hoger beroep worden ingesteld binnen drie maanden na betekening daarvan of nadat de beschikking hem bekend is geworden. Bij onduidelijkheid over het aanvangsmoment van de termijn zal degene die beroep instelt voldoende gemotiveerd moeten stellen dat hij op een bepaald tijdstip met de beschikking bekend is geworden. ${ }^{11}$ Indien vaststaat dat de beschikking door de rechtbank naar de belanghebbende is gezonden en door de belanghebbende is ontvangen, is het hof niet verplicht om te verifiëren wanneer de belanghebbende de beschikking heeft ontvangen. Het is aan de belanghebbende om helderheid te verschaffen over het tijdstip van ontvangst. ${ }^{12}$

Aan een verzoeker en de andere in de procedure verschenen belanghebbende(n) deelt de rechter na afloop van de behandeling mee op welke dag hij uitspraak zal doen (art. 286 Rv). Als dit ook daadwerkelijk gebeurt, bestaat geen aanleiding om een termijnoverschrijding verschoonbaar te achten. ${ }^{13}$ Toch kan het onvoldoende zijn als de rechter meedeelt 'over

8. HR 11 juli 2014, ECLI:NL:HR:2014:1638, JBPr 2014/53 en ECLI:NL:HR:2014:1682, JBPr 2014/54 m.nt. Venhuizen.

9. HR 28 november 2003, ECLI:NL:HR:2003:AN8489, NJ 2005/465 m.nt. Asser; HR 24 april 2009, ECLI:NL:HR:2009:BH3192, NJ 2009/488 m.nt. Van Mierlo; HR 27 mei 2011, ECLI:NL:HR: 2011:BQ0510, NJ 2012/626 m.nt. Snijders.

10. HR 21 februari 2014, ECLI:NL:HR:2014:413, NJ 2014/131.

11. Zie Hammerstein, T\&C Rv, art. 358, aant. 2.

12. Conclusie A-G Wesseling-van Gent voor HR 15 februari 2013 , ECLI:NL:HR:2013:BY5049.

13. HR 28 november 2003, ECLI:NL:HR:2003:AN8489, NJ 2005/465, HR 10 juni 2005, ECLI:NL:HR:2005:AT1097, NJ 2005/372 en HR 21 februari 2014, ECLI:NL:HR:2014:413, NJ 2014/131. 
twee weken' uitspraak te doen. In een dergelijk geval, waarbij de verzoeker in eerste aanleg niet werd bijgestaan door een advocaat en hem niet de precieze dag van de uitspraak was meegedeeld onder vermelding dat hij vanaf dat moment telefonisch naar de uitspraak kon informeren, oordeelde de Hoge Raad dat sprake was van een verzuim van de rechtbank, als gevolg waarvan de verzoeker redelijkerwijs niet hoefde te weten op welke dag uitspraak was gedaan. ${ }^{14} \mathrm{Na}$ terugwijzing ging het in deze zaak opnieuw mis. Het hof achtte op grond van de poststempel van de rechtbank voldoende aannemelijk dat de verzoeker de uitspraak voor het verstrijken van de beroepstermijn had ontvangen, maar de Hoge Raad oordeelt met de A-G dat dit, gelet op de mogelijke postblokkade, het verzuim van de rechtbank om op de envelop te vermelden 'van de rechtbank aan saniet' en de mededeling van de bewindvoerder dat hij niet weet of op zijn adres zowel het voor hem als voor verzoeker bestemde afschrift van de uitspraak is bezorgd, onvoldoende zekerheid biedt dat de verzoeker het vonnis inderdaad tijdig heeft ontvangen. ${ }^{15}$

De gedaagde die bij verstek is veroordeeld in een vonnis dat volgens art. 140 lid $3 \mathrm{Rv}$ als een vonnis op tegenspraak geldt (omdat ten minste één van de medegedaagden wel is verschenen en tussen alle partijen één vonnis is gewezen), kan niet in verzet, maar heeft alleen het rechtsmiddel van hoger beroep. ${ }^{16}$ Ook dan geldt - als een regel van openbare orde - de normale beroepstermijn van drie maanden van art. $339 \mathrm{Rv}$. Maar de toepassing van art. 140 en 339 Rv mag er niet toe leiden dat het recht op toegang tot de rechter in de kern wordt aangetast. ${ }^{17}$ Dit kan betekenen dat de overschrijding van de appeltermijn toch niet fataal is, zoals in het geval waarin de inleidende dagvaarding niet in persoon is betekend en het vonnis aan de bij verstek veroordeelde niet bekend is geworden voorafgaand aan het verstrijken van de appeltermijn. Indien de veroordeelde hoger beroep heeft ingesteld binnen een redelijke termijn, is hij toch ontvankelijk. Die termijn bedraagt veertien dagen of zoveel minder als overeenstemt met een kortere wettelijke beroepstermijn, en vangt aan op de dag volgend op die waarop het vonnis aan de veroordeelde in persoon is betekend dan wel deze anderszins met het vonnis bekend is geraakt. ${ }^{18}$

\section{Financiële appelgrens}

Hoger beroep staat niet open in zaken waarin de vordering waarover de rechter in eerste aanleg had te beslissen niet meer beloopt dan $€ 1750$ of, in geval van een vordering van onbepaalde waarde, er duidelijke aanwijzingen bestaan dat de vordering geen hogere waarde vertegenwoordigt dan $€ 1750$, een en ander tenzij de wet anders bepaalt. Deze financiële appelgrens van art. $332 \mathrm{Rv}$ heeft als ratio dat geen hoger beroep behoort open te staan in zaken waarin het betrekkelijk geringe financiële belang niet opweegt tegen de tijd en kosten die

14. HR 11 juli 2014, ECLI:NL:HR:2014:1682, JBPr 2014/54 m.nt. Venhuizen.

15. HR 30 januari 2015, ECLI:NL:HR:2015:189.

16. Zie voor een toepassing hiervan Hof Arnhem-Leeuwarden 5 november 2013, ECLI:NL:GHARL:2013:8312, JBPr 2014/20 m.nt. Gras.

17. Vgl. HR 21 februari 2014, ECLI:NL:HR:2014:413, NJ 2014/131.

18. HR 3 oktober 2014, ECLI:NL:HR:2014:2894. gemoeid zijn met de behandeling van de zaak in hoger beroep. ${ }^{19}$

Voor de toepassing van de appelgrens is bepalend het totale beloop of de totale waarde van het gevorderde, ook indien de zaak meer dan één vordering tussen dezelfde partijen (objectieve cumulatie) betreft. Dat wordt niet anders indien de rechter over het gevorderde beslist in meer (deel)vonnissen. Ook in dat geval dient voor de appellabiliteit van elk van die deelvonnissen in aanmerking te worden genomen wat het totale beloop of de totale waarde was van het gevorderde waarover de rechter in eerste aanleg had te beslissen. ${ }^{20}$ Daarbij geldt dat een wijziging van eis (uitsluitend) gevolgen kan hebben voor de appellabiliteit van vonnissen die na deze eiswijziging worden uitgesproken. De aard van de zaak is voor de beoordeling van de appellabiliteit niet van belang, een eisvermindering in eerste aanleg wel. ${ }^{21}$ Een niet-appellabel vonnis kan niet appellabel worden gemaakt door in hoger beroep een gewijzigde vordering of een nieuwe vordering in te stellen. ${ }^{22}$

\section{Hoger beroep van tussenuitspraken}

Tussentijds hoger beroep is niet mogelijk van tussenuitspraken, tenzij de rechter anders heeft bepaald (art. 337 lid 2 Rv). ${ }^{23}$ Ook een arrest dat is gewezen op een hoger beroep dat is ingesteld tegen een tussenvonnis, is een tussenarrest, zolang daarin niet omtrent enig deel van het gevorderde een einde wordt gemaakt in het dictum. Daarvan is geen tussentijds cassatieberoep mogelijk, tenzij het hof anders heeft bepaald. ${ }^{24}$ Een oordeel over de bewijslastverdeling maakt een beschikking of arrest niet tot een einduitspraak waartegen tussentijds cassatieberoep mogelijk is. ${ }^{25}$

Er staat alleen hoger beroep open (al dan niet tegelijk met de einduitspraak) van (tussen)uitspraken die bindende eindbeslissingen bevatten. Tegen een tussenuitspraak kan slechts eenmaal hoger beroep worden ingesteld. Een partij die tussentijds hoger beroep instelt, is gehouden daarin al haar bezwaren tegen eindbeslissingen in de tot dan toe gewezen tussenvonnissen aan te voeren en die partij verliest dus de mogelijkheid om

19. Zie Snijders/Wendels 2009/30-31 en Asser Procesrecht/Bakels, Hammerstein \& Wesseling-van Gent 4 2012/10-21.

20. HR 18 april 2014, ECLI:NL:HR:2014:946, NJ 2014/224, JBPr 2014/37 m.nt. Lombert en Wiersma.

21. HR 29 november 2013, ECLI:NL:HR:2013:1468.

22. HR 8 februari 2013, ECLI:NL:HR:2013:BY2599, NJ 2013/102.

23. Zie hierover uitgebreid S.M. Kingma, Tussentijds beroep tegen tussenuitspraken en deeluitspraken, TCR 2010, afl. 1, p. 5-12.

24. HR 22 februari 2013, ECLI:NL:HR:2013:BY4466.

25. Conclusie A-G Wesseling-van Gent voor HR 1 maart 2013, ECLI:NL:HR:2013:BY6100. 
dat bij een latere gelegenheid alsnog of nogmaals te doen. ${ }^{26}$ Voor voorlopige beslissingen geldt dat niet.

Het enkele toelaten tot bewijslevering is geen bindende eindbeslissing, maar een voorlopige beslissing. ${ }^{27}$ In de vorige kroniek twijfelde ik erover of een bewijsopdracht waarbij de rechter zich wel uitspreekt over de bewijslastverdeling maar nog niet uitdrukkelijk en zonder voorbehoud overweegt hoe over de zaak beslist zal worden ingeval het opgedragen bewijs wel respectievelijk niet geleverd wordt, als een eindbeslissing kwalificeert. Lewin en Krans legden het arrest van de Hoge Raad van 30 maart 2012 in dat opzicht verschillend uit. ${ }^{28}$ Volgens A-G Wesseling-van Gent is het vaste jurisprudentie dat een oordeel over de bewijslastverdeling een voorlopige beslissing is en geen bindende eindbeslissing. ${ }^{29}$ Toch is dat maar de vraag. Er lijkt veel voor te zeggen dat ook een bewijsopdracht waarbij een oordeel is gegeven over de bewijslastverdeling, een eindbeslissing is waartegen (met toestemming) tussentijds geappelleerd kan worden. In Ydo/Baljeu sprake de Hoge Raad reeds over 'de eindbeslissing over de bewijslastverdeling' (r.o. 3.3.4 $)^{30}$ en ook in HR 14 juni 2013 overweegt de Hoge Raad dat het bestreden oordeel van het hof niet slechts een bewijsopdracht betreft, maar ook 'een eindbeslissing bevat omtrent de bewijslast', ${ }^{31}$ terwijl van een uitdrukkelijk en zonder voorbehoud gegeven overweging van het hof over hoe de zaak na bewijslevering zou worden beslist geen sprake was. Overigens, maar dat terzijde, komt de Hoge Raad via een bijzondere redenering tot de beoordeling dat in dit geval een beslissing omtrent de bewijslast(verdeling) was gegeven. Omdat het hof toestemming had gegeven tussentijds cassatieberoep in te stellen tegen het tussenarrest met een bewijsbeslissing, moet het tussenarrest wel een bindende eindbeslissing bevatten over de verdeling van de bewijslast; anders had het hof die toestemming immers wel geweigerd, aldus de Hoge Raad. Een weinig fraai 'bewijs uit het ongerijmde', zo lijkt me. De beslissing valt in zoverre positief te waarderen dat de praktijk met deze redenering goed uit de voeten kan vanwege de verschafte duidelijk-

26. Zie o.a. HR 30 maart 2012, ECLI:NL:HR:2012:BU3160, NJ 2012/582 m.nt. Krans, JBPr 2012/41. Zie over deze 'eenmaal schieten regel' in geval van deeluitspraken o.a. R.S. Meijer, Tussentijds beroep van deelvonnissen. Een kwestie van willen, mogen en moeten, in: R.S. Meijer e.a. (red.), Uit de praktijk (Liber amicorum mr. P.J.M. von Schmidt auf Altenstadt), Den Haag: Boom Juridische uitgevers 2012 en B.T.M. van der Wiel, Niet geschoten, altijd mis. Over het opkomen tegen beslissingen uit een onbestreden deeluitspraak bij beroep tegen een daaropvolgende uitspraak, in: P.J.M. von Schmidt auf Altenstadt e.a. (red.), Middelen voor Meijer (Liber amicorum mr. R.S. Meijer), Den Haag: Boom Juridische uitgevers 2013.

27. HR 30 maart 2012, ECLI:NL:HR:2012:BU3160, JBPr 2012/41, NJ 2012/582 m.nt. Krans.

28. JBPr 2012/42 m.nt. Lewin, NJ 2012/582 m.nt. Krans.

29. Conclusie A-G Wesseling-van Gent voor HR 1 maart 2013, ECLI:NL:HR:2013:BY6100.

30. HR 30 maart 2012, ECLI:NL:HR:2012:BU3160, JBPr 2012/41, NJ 2012/582 m.nt. Krans.

31. ECLI:NL:HR:2013:BZ5356, JBPr 2013/51 m.nt. Wieten, NJ 2013/343. heid. ${ }^{32}$ Intussen vraagt Asser zich hardop af of het wel verstandig is om bewijsbeslissingen aan te merken als bindende eindbeslissingen en pleit hij ervoor om bewijsbeslissingen juist als voorlopig aan te merken, om de handen van de rechter niet vroegtijdig te binden. ${ }^{33}$

Indien de rechtbank tussentijds cassatieberoep heeft opengesteld, terwijl de rechtbank niet in hoogste ressort of als appelrechter oordeelde en partijen geen sprongcassatie zijn overeengekomen, moet dit worden begrepen als een toestemming om tussentijds hoger beroep in te stellen. ${ }^{34}$ Als ten onrechte toch tussentijds cassatieberoep wordt ingesteld, hoeft dit overigens niet fataal te zijn. Ingevolge art. $340 \mathrm{Rv}$ vangt met de uitspraak in cassatie de termijn van hoger beroep opnieuw aan, mits het beroep in cassatie werd ingesteld binnen de appeltermijn.

Van beslissingen op provisionele vorderingen ex art. 223 Rv kan ingevolge art. 337 lid $1 \mathrm{Rv}$ onmiddellijk hoger beroep worden ingesteld. Inmiddels weten we dat ook in een verzoekschriftprocedure een incidenteel verzoek kan worden gedaan tot het treffen van een voorlopige voorziening voor de duur van het geding, overeenkomstig hetgeen art. $223 \mathrm{Rv}$ bepaalt voor de dagvaardingsprocedure. ${ }^{35}$ Op een dergelijk verzoek zal in de regel eerst en vooraf worden beslist. In afwijking van de hoofdregel van art. 358 lid $1 \mathrm{Rv}$ kan daarvan hoger beroep worden ingesteld voordat de eindbeschikking wordt gewezen.

\section{Doorbreking van het rechtsmiddelenverbod}

Als uitgangspunt geldt dat uitspraken vatbaar zijn voor hoger beroep, tenzij het tegendeel uit de wet voortvloeit. ${ }^{36}$ Als tegen een uitspraak geen rechtsmiddel (meer) openstaat, heeft deze - onherroepelijk - rechtskracht tussen partijen. Dat geldt ook indien achteraf blijkt dat de grondslag waarop de uitspraak berust, is weggevallen. Een onjuiste rechterlijke uitspraak kan - afgezien van het zeldzame geval van het geheel ontbreken van rechtskracht - niet anders dan door het aanwenden van een rechtsmiddel worden aangetast en ook indien geen rechtsmiddel beschikbaar is, heeft de uitspraak tussen partijen rechtskracht. Zo konden de erfgenamen van een werknemer aanspraak maken op de door de kantonrechter aan de erflater toegekende ontbindingsvergoeding, ook al was de erflater tussen de datum van de uitspraak en de datum waartegen de arbeidsovereenkomst zou worden ontbonden, komen te overlijden. ${ }^{37}$ Aan een ontbindingsbeschikking als bedoeld in art. 7:685 van het Burgerlijk Wetboek (BW) komt, zo overweegt de Hoge Raad in overeenstemming met bestendige

32. Ook in HR 20 maart 2015, ECLI:NL:HR:2015:661, r.o. 4.4 weegt de omstandigheid dat het hof tussentijds cassatieberoep heeft opengesteld, mee bij het oordeel dat het hof kennelijk eindbeslissingen heeft willen nemen.

33. Zie hierover de noot van Asser onder HR 11 september 2012, ECLI:NL:HR:2012:BX0737, NJ 2014/480.

34. HR 11 oktober 2013, ECLI:NL:HR:2013:910, JBPr 2014/5 m.nt. Van der Voort Maarschalk, NJ 2013/493.

35. HR 5 december 2014, ECLI:NL:HR:2014:3533.

36. Asser /Bakels, Hammerstein \& Wesseling-van Gent 4 2012/10; zie ook HR 18 april 2014, ECLI:NL:HR:2014:948, JBPr 2014/31, r.o. 3.3.3.

37. HR 3 oktober 2014, ECLI:NL:HR:2014:2898, JAR 2014/277 m.nt. Fruijtier, Prg. 2014/297. 
jurisprudentie, ${ }^{38}$ niet slechts rechtskracht toe indien de arbeidsovereenkomst op het in de beschikking bepaalde tijdstip van ontbinding nog steeds bestaat, want dan zou aan een onherroepelijke rechterlijke uitspraak zonder aanwending van een rechtsmiddel rechtskracht kunnen worden ontzegd door in een volgend geding te doen vaststellen dat de uitspraak geen rechtskracht heeft gekregen of dat de rechtskracht daaraan is ontvallen omdat de grondslag waarop de uitspraak berustte, is weggevallen. Dat is onverenigbaar met het gesloten stelsel van rechtsmiddelen.

Een in de wet opgenomen rechtsmiddelenverbod kan volgens vaste rechtspraak worden doorbroken indien erover geklaagd wordt dat de rechter de desbetreffende regel ten onrechte niet heeft toegepast, buiten het toepassingsgebied van de desbetreffende regel is getreden of bij het nemen van zijn beslissing zodanig essentiële vormen niet in acht heeft genomen dat niet meer kan worden gesproken van een eerlijke en onpartijdige behandeling van de zaak. ${ }^{39} \mathrm{Als}$ één of meer van deze doorbrekingsgronden worden aangevoerd, is een hoger beroep, ondanks een appelverbod, toch ontvankelijk. Vervolgens zal moeten worden beoordeeld of er terecht een beroep is gedaan op een doorbrekingsgrond. Indien blijkt dat zich geen doorbrekingsgrond voordoet, moet het hoger beroep alsnog worden verworpen. Aan een bekrachtiging of vernietiging van het bestreden vonnis komt de appelrechter dan niet toe. Indien er wel terecht een beroep is gedaan op een doorbrekingsgrond, dient de appelrechter over te gaan tot een inhoudelijke (her)beoordeling van de zaak. ${ }^{40}$

Deze mogelijkheid om een rechtsmiddelenverbod te doorbreken geldt niet altijd. Tegen de beslissing een eiswijziging of -vermeerdering al dan niet toe te staan, staat ingevolge het bepaalde in art. 130 lid $2 \mathrm{Rv}$ geen hogere voorziening open. Volgens bestendige jurisprudentie kan dit rechtsmiddelenverbod niet worden doorbroken, ook niet als zich doorbrekingsgronden, zoals hiervoor benoemd, voordoen. ${ }^{41}$ Dat vindt de Hoge Raad nog steeds. ${ }^{42}$

Ook het verbod om tussentijds in hoger beroep te komen van een (zuivere) tussenuitspraak (art. 337 lid 2 en 358 lid 1 $\mathrm{Rv}$ ) leent zich niet voor doorbreking. Die bepaling sluit de bevoegdheid tot appel niet uit, maar regelt slechts het moment waarop deze bevoegdheid kan worden uitgeoefend, en daarvoor is de doorbrekingsjurisprudentie niet bedoeld. ${ }^{43}$ Dat deed de vraag rijzen of deze jurisprudentie al dan niet geldt bij beslissingen in het kader van de zogenoemde deelgeschilprocedure. De Hoge Raad heeft die vraag inmiddels bevestigend beantwoord. ${ }^{44}$ Daartoe overweegt de Hoge Raad dat de beschikking op een deelgeschil als bedoeld in art. 1019w Rv

38. Zie bijv. HR 1 april 2011, ECLI:NL:HR:2011:BP2312, NJ 2011/220.

39. HR 10 februari 2012, ECLI:NL:HR:2012:BU7255, NJ 2012/230.

40. Zie bijv. HR 14 juni 2013, ECLI:NL:HR:2013:BZ5666, NJ 2014/235 m.nt. Huydecoper.

41. HR 28 mei 1999, ECLI:NL:HR:1999:ZC2914, NJ 2000/220 m.nt. Vranken.

42. HR 8 februari 2013, ECLI:NL:HR:2013:BY2599, NJ 2013/102.

43. HR 28 september 2012, ECLI:NL:HR:2012:BX0598, NJ 2012/556.

44. HR 18 april 2014, ECLI:NL:HR:2014:943, JAR 2014/125 m.nt. Dempsey. bindende eindbeslissingen kan behelzen op geschilpunten die de materiële rechtsverhouding tussen partijen betreffen, waartegen (op enig moment) een rechtsmiddel openstaat (en waarvoor doorbreking dus niet nodig is), maar dat de beschikking ook beslissingen van andere aard kan omvatten, waartegen niet (ook niet later) een rechtsmiddel openstaat. Omdat niet steeds op voorhand duidelijk behoeft te zijn wat de precieze reikwijdte van de in de beschikking opgenomen beslissingen is, roept dat onzekerheid op. Die onzekerheid verdraagt zich niet met de rechtszekerheid die moet bestaan omtrent de vraag of een bepaald wettelijk rechtsmiddelenverbod kan worden doorbroken. Daarom, aldus de Hoge Raad, moet worden aangenomen dat de doorbrekingsjurisprudentie ook geldt met betrekking tot een beschikking op de voet van art. 1019w Rv, ongeacht of een rechtsmiddel in de zin van art. 1019cc lid 3 Rv openstaat of zal openstaan. Over de vraag of dit hoger beroep moet worden ingeleid met een beroepschrift of met een appeldagvaarding bestaat nog geen eenduidigheid: het Gerechtshof Den Bosch meent het eerste, ${ }^{45}$ het Gerechtshof Arnhem-Leeuwarden het laatste. ${ }^{46}$

Als het hof een beroep op een doorbrekingsgrond heeft afgewezen, en het hoger beroep dus heeft verworpen, en er vervolgens herroeping wordt gevorderd wegens bedrog (art. 382 $\mathrm{Rv}$ ), dan geldt de rechter in eerste aanleg als de rechter die in laatste feitelijke instantie over de zaak heeft geoordeeld in de zin van art. $384 \mathrm{Rv} .{ }^{47}$ Een vordering tot herroeping dient dan bij de rechter in eerste aanleg te worden aangebracht.

\section{Eén appeldagvaarding tegen meerdere uitspraken}

Het is in het algemeen in strijd met een goede procesorde om bij één dagvaarding beroep in te stellen tegen uitspraken die in verschillende procedures zijn gedaan. Een belangrijke uitzondering op deze regel vormt het geval dat bij één dagvaarding in beroep wordt gekomen tegen twee uitspraken die zijn gewezen op dezelfde dag door dezelfde rechter tussen dezelfde partijen. Het moet daarbij dan gaan om 'gedingen die betrekking hebben op vorderingen die gewoonlijk verenigd aan de rechter worden voorgelegd maar in dit geval ieder in een afzonderlijk geding zijn ingesteld'. ${ }^{48}$ Deze regel geldt nog steeds, zij het dat de Hoge Raad de eis dat het moet gaan om 'gewoonlijk verenigde' vorderingen iets anders formuleert: beide zaken moeten voldoende met elkaar samenhangen om gezamenlijk door de rechter te worden behandeld en beslist. ${ }^{49}$ Ook wanneer het gaat om uitspraken die tussen verschillende partijen zijn gewezen, is ontvankelijkheid van de bij één exploot ingestelde

45. Zie <www.letselschademagazine.nl/2014/hof-s-hertogenbosch-11021 $4>$.

46. Hof Arnhem-Leeuwarden 12 augustus 2014, ECLI:NL:GHARL: 2014:6361 en 6362, Prg. 2014/274.

47. HR 5 december 2014, ECLI:NL:HR:2014:3536.

48. HR 7 maart 1980, ECLI:NL:HR:1980:AB7499, NJ 1980/611 en HR 19 februari 2010, ECLI:NL:HR:2010:BK8100, NJ 2010/116. Zie voor een overzicht van de recente rechtspraak hierover de conclusie van A-G Huydecoper voor HR 12 oktober 2012, ECLI:NL:HR:2012:BX5801, NJ 2012/587, JBPr 2013/25 m.nt. Teuben. Zie verder Snijders/Wendels $2009 / 139$.

49. HR 21 juni 2013, ECLI:NL:HR:2013:BZ8317, NJ 2014/248 m.nt. Snijders. 
rechtsmiddelen niet uitgesloten, maar stelt de Hoge Raad een strengere eis. In dat geval moet ook aanstonds voldoende vaststaan dat een genoegzame samenhang bestaat tussen de verschillende zaken om een gezamenlijke behandeling daarvan te rechtvaardigen. Dit laatste kan onder meer worden aangenomen als in een eerdere instantie een voeging van die zaken heeft plaatsgevonden, maar een vereiste is dat niet. Wat er nu precies strenger is aan deze eis ingeval sprake is van verschillende partijen ten opzichte van de situatie dat sprake is van dezelfde partijen, is niet zonneklaar. In geval van verschillende partijen lijken aan de samenhang zwaardere eisen te worden gesteld, wil een gecombineerd rechtsmiddel ontvankelijk zijn, maar concreter dan dat wordt het niet gemaakt. Voldoende is dat het gaat om identieke vorderingen met een grote onderlinge samenhang, terwijl de bestreden vonnissen gelijkluidend zijn. ${ }^{50}$ Maar de onzekerheid over de invulling van dit criterium maakt dat het verstandig blijft om bij afzonderlijke exploten hoger beroep in te stellen, om vervolgens voeging van de zaken te vorderen. Het risico om niet-ontvankelijk verklaard te worden omdat er onvoldoende samenhang tussen de verschillende zaken blijkt te zijn, zou mij - ware ik advocaat van de appellerende partij - te groot zijn ten opzichte van de relatief geringe besparing van explootkosten (en griffierechten?) ${ }^{51}$ die het oplevert. Let wel: die niet-ontvankelijkheid strekt zich dan uit tot al de zaken waarvan bij het ene exploot hoger beroep werd ingesteld, zodat de cliënt met lege handen achterblijft en een telefoontje naar de beroepsaansprakelijkheidsverzekeraar het enige lijkt te zijn dat rest.

\section{Verzet in hoger beroep}

Een geïntimeerde die in hoger beroep verstek laat gaan, kan tegen het bij verstek gewezen arrest verzet instellen. Het rechtsmiddel van verzet heeft als strekking dat het geding waarin verstek was verleend, wordt heropend en op tegenspraak in dezelfde instantie wordt voortgezet (art. 147 lid 1 $\mathrm{Rv})$. De verzetdagvaarding heeft dan te gelden als de memorie van antwoord (art. 147 lid 1 jo. art. 353 lid 1 Rv). De opposant, oorspronkelijk geïntimeerde, zal dus niet kunnen volstaan met het uitbrengen van een blanco dagvaarding. ${ }^{52}$ Indien in de verzetdagvaarding geen gronden worden aangevoerd, bestaat niet het recht om alsnog een memorie van antwoord te nemen. ${ }^{53}$ Het staat de geïntimeerde vrij om in de verzetdagvaarding in incidenteel hoger beroep grieven te richten tegen onderdelen van het vonnis in eerste aanleg die niet werden bestreken door de grieven van de appellant. ${ }^{54}$

Als abusievelijk een verstekarrest is gewezen terwijl het een arrest op tegenspraak had moeten zijn, staat geen verzet open,

50. HR 4 oktober 2013, ECLI:NL:HR:2013:848, conclusie A-G De Vries Lentsch-Kostense onder 16.

51. Zie hierover ook de noot van K. Teuben onder HR 12 oktober 2012, ECLI:NL:HR:2012:BX5801, JBPr 2013/25.

52. Van Geuns, GS Burgerlijke rechtsvordering, art. 353 Rv, aant. 2.

53. Aldus Hof Arnhem-Leeuwarden 1 juli 2014, ECLI:NL:GHARL: 2014:5261.

54. HR 4 oktober 2013, ECLI:NL:HR:2013:CA3741, JBPr 2014/3 m.nt. Janssen, NJ 2014/142 m.nt. Strikwerda. maar alleen cassatieberoep: het wezen van de uitspraak prevaleert boven de vorm waarin deze is uitgesproken. ${ }^{55}$

\section{Akte niet-dienen}

Een rechterlijk orgaan is bevoegd tot het vaststellen van een procesreglement. Dat mag een landelijk, maar ook een lokaal reglement zijn. Een procesreglement dat door een daartoe bevoegd rechterlijk orgaan is vastgesteld en behoorlijk bekend is gemaakt, moet worden aangemerkt als recht in de zin van art. 79 van de Wet op de rechterlijke organisatie (Wet RO).56

Ingevolge art. 1.7 van het Landelijk procesreglement voor civiele dagvaardingszaken bij de gerechtshoven (LPR) kan een partij de aan de wederpartij gegeven termijn om een proceshandeling te verrichten verkorten, of een nieuw uitstel voorkomen, door de wederpartij partijperemptoir en akte nietdienen aan te zeggen. De vereisten waaraan de aanzegging van akte niet-dienen in hoger beroep moet voldoen, zijn vastgelegd in art. 2.13 LPR. Indien op een juiste wijze partijperemptoir en akte niet-dienen is aangezegd tegen een bepaalde roldatum en de vereiste proceshandeling op die roldatum niet wordt verricht, verleent de rolraadsheer in beginsel op dat moment akte niet-dienen. Daarmee vervalt het recht om die proceshandeling te verrichten.

De bevoegdheid van de rechter om na een peremptoirstelling met het verlenen van akte niet-dienen te beslissen dat het recht om een memorie van grieven te nemen vervallen is verklaard, vloeit voort uit art. 133 lid 4 Rv. Art. 133 lid 4 Rv is op zijn beurt weer een uitwerking van art. $20 \mathrm{Rv}$. Daarin is de rechter opgedragen te waken tegen onredelijke vertraging van de procedure (lid 1) en zijn partijen ook tegenover elkaar verplicht onredelijke vertraging van de procedure te voorkomen (lid 2). De rechter zal zo nodig, op verzoek van een partij of ambtshalve, daartoe maatregelen moeten treffen, bijvoorbeeld door te bepalen dat het recht om te concluderen of een akte te nemen is vervallen. De beslissing van de rolraadsheer om akte niet-dienen van de memorie van grieven te verlenen, betreft een tussenarrest waartegen, na verkregen verlof, tussentijds cassatieberoep kan worden ingesteld. Dat geldt ook voor de weigering van de rolraadsheer om op zijn eerdere beslissing terug te komen. Daarbij is niet doorslaggevend of de beslissing op papier is gesteld; ook een telefonisch meegedeelde beslissing kan een tussenarrest zijn. ${ }^{57}$

Uitgangspunt in de jurisprudentie van de Hoge Raad is dat een advocaat op grond van zijn deskundigheid en kennis zonder meer geacht wordt op de hoogte te zijn van de geldende termijnen en van de verstrekkende gevolgen die verbonden zijn aan overschrijding daarvan. ${ }^{58}$ Als hij zich niet aan deze termijnen houdt, en akte niet-dienen wordt verleend, valt

55. Zie voor een toepassing hiervan Hof Den Bosch 10 maart 2015 ECLI:NL:GHSHE:2015:827.

56. Herhaald door de Hoge Raad op 17 maart 2015, ECLI:NL:HR: 2015:1064.

57. Conclusie A-G Wesseling-van Gent voor HR 28 maart 2014, ECLI:NL:PHR:2014:79.

58. Vgl. HR 11 oktober 2013, ECLI:NL:HR:2013:CA0721, NJ 2013/491, JBPr 2014/4 m.nt. Van der Voort Maarschalk. 
daarmee in beginsel het doek. Op deze regel heeft zich in de kroniekperiode een aantal uitzonderingen voorgedaan.

In ECLI:NL:HR:2014:2813 was abusievelijk, ondanks een juiste aanzegging van akte niet-dienen door de wederpartij, in het roljournaal vermeld dat uitstel was verleend. ${ }^{59}$ Dit werd binnen twee dagen gecorrigeerd en op de aangezegde datum werd akte niet-dienen verleend. Bij eindarrest werd het hoger beroep van appellant wegens het ontbreken van een memorie van grieven verworpen. De Hoge Raad casseert. Gelet op de functie van het roljournaal ('een voor advocaten door middel van het internet toegankelijke weergave van het op de rol verhandelde') mocht de advocaat ervan uitgaan dat het roljournaal een juiste weergave bevatte van hetgeen op de rol beslist was, en behoefde hij niet te controleren of dit nog werd gecorrigeerd. Daaraan doet niet af dat art. 1.12 LPR de hoven twee dagen de tijd geeft om het op de rol verhandelde in het roljournaal bekend te maken. Bij de beslissing van de Hoge Raad weegt mee dat de appellant om uitstel had verzocht en dat hij uit de vermelding in het roljournaal mocht afleiden dat het uitstelverzoek was ingewilligd. Ik maak me evenwel sterk dat ook indien dat uitstelverzoek niet was gedaan, de beslissing van de Hoge Raad niet anders was uitgevallen. De boodschap lijkt te zijn dat partijen niet de dupe mogen worden van administratieve vergissingen of onduidelijkheden van het gerecht. ${ }^{60}$ Dat wil niet zeggen dat het hof de vergissing niet mocht corrigeren, maar het hof had partijen zo spoedig mogelijk (uitdrukkelijk, dus niet alleen door een correctie in het roljournaal, en voldoende tijdig) moeten meedelen dat er een onjuiste vermelding was opgenomen en dat dit was hersteld.

Ook in ECLI:NL:HR:2014:2798 was akte niet-dienen verleend en was appellant wegens het niet dienen van grieven niet-ontvankelijk verklaard in zijn hoger beroep. ${ }^{61}$ En opnieuw ging de zaak in cassatie 'over de kop' wegens administratieve misverstanden. Wat was het geval? Hof Den Bosch hanteert een pilotreglement ter bevordering van snellere doorlooptijden. In het pilotreglement is in minder ruime uitstelmogelijkheden voorzien dan in het LPR. Volgens dit reglement wordt er na de eerste termijn van zes weken voor grieven nog slechts eenmaal een uitstel verleend van vier weken, waarna, indien dan geen grieven worden genomen, ambtshalve akte niet-dienen wordt verleend. Volgens het pilotreglement moeten verzoeken tot uitstel worden ingediend door middel van een zogenoemd $\mathrm{H} 5$-formulier. Maar dit formulier was (nog) niet aangepast aan de Bossche pilot; het verwees nog steeds naar het LPR, met zijn ruimere uitstelmogelijkheden. Hoewel de op het $\mathrm{H} 5$-formulier vermelde uitstelmogelijkheden in strijd waren met de beperktere uitstelmogelijkheden van het pilotreglement, mocht de advocaat van appellant op de juistheid van dat formulier afgaan.

In ECLI:NL:HR:2014:2804 speelde hetzelfde pilotreglement een rol, maar werd de beslissing van het gerechtshof om (ambtshalve) akte niet-dienen te verlenen gecasseerd op de

59. HR 26 september 2014, NJ 2014/417.

60. Zie ook HR 29 maart 2013, ECLI:NL:HR:BY7843, JBPr 2013/38 m.nt. Vos.

61. HR 26 september 2014, NJ 2014/418. grond dat het hof niet tijdig had duidelijk gemaakt of het verzoek tot uitstel was toegestaan. ${ }^{62}$ Art. 1.9 van het pilotreglement (dat identiek is aan art. 1.9 LPR) schrijft voor dat verzoeken tot uitstel worden ingediend uiterlijk vier dagen voor de roldatum waarop de proceshandeling waarvoor uitstel wordt verzocht, moet worden verricht. Deze bepaling strekt ertoe, aldus de Hoge Raad, ${ }^{63}$ dat vóór afloop van de desbetreffende termijn komt vast te staan of het gevraagde uitstel al dan niet wordt verleend, klaarblijkelijk opdat - in het laatste geval - de verzoeker de gelegenheid heeft de proceshandeling waarvoor uitstel was gevraagd zo mogelijk alsnog tijdig te verrichten. Een beslissing op een tijdig ingediend verzoek om uitstel moet daarom in alle gevallen (ook als niet het juiste $\mathrm{H}$ formulier is gebruikt of geen klemmende redenen worden genoemd, terwijl dat wel de enige grond is waarop een uitstel kan worden verkregen) op een zodanig tijdstip worden gegeven dat in geval van weigering de verzoeker nog de gelegenheid heeft om de proceshandeling toch nog tijdig te verrichten. Die beslissing kan dus niet pas worden gegeven op de roldatum waarop de proceshandeling zonder uitstel verricht moet worden. Voor de praktijk betekent dit dat niet alle rolbeslissingen op de roldatum kunnen worden genomen, maar dat bij elk binnenkomend uitstelverzoek moet worden beoordeeld of het uitstel betreft van een peremptoire proceshandeling en of daarop onmiddellijk moet worden beslist.

De bepaling in het Bossche pilotreglement dat per telefax ingediende processtukken niet in behandeling worden genomen, leidde ook tot een (ambtshalve) verlening van akte nietdienen. De (tijdig) per fax ingediende memorie van grieven was geweigerd, terwijl de per post ingediende memorie van grieven buiten de termijn werd ontvangen en daarom niet in behandeling werd genomen. Dit kan volgens de Hoge Raad niet door de beugel van art. $33 \mathrm{Rv}^{64}$ Deze bepaling moet - gelet op de wetsgeschiedenis - zo worden uitgelegd dat voor faxverkeer is blijven gelden de in 2002 gecodificeerde regel dat stukken die door middel van faxapparatuur vóór 24.00 uur van de laatste dag van een lopende termijn ter griffie zijn ontvangen, gelden als binnen de termijn ingediend. De desbetreffende bepaling uit het pilotreglement is daarmee in strijd en dan ook in zoverre onverbindend. Dit treft overigens ook de andere hoven omdat art. 2.1 LPR identiek is aan de onverbindend geoordeelde bepaling uit het pilotreglement.

De uitvoering van een door het Gerechtshof Amsterdam gehanteerd pilotreglement moest het op de valreep van deze kroniekperiode eveneens in cassatie ontgelden. ${ }^{65}$ Ingevolge dit van het LPR afwijkende rolreglement is sprake van één termijn voor het indienen van memories, die niet wordt verlengd, terwijl bij overschrijding van die termijn zonder peremptoirstelling of voorafgaande waarschuwing ambtshalve akte nietdienen wordt verleend. In een principieel getoonzette uitspraak overweegt de Hoge Raad dat, zeker waar de toegang tot

62. HR 26 september 2014, NJ 2014/419.

63. In gelijke zin HR 17 juni 2011, ECLI:NL:HR:2011:BQ1774, NJ 2013/376.

64. HR 17 april 2015, ECLI:NL:HR:2015:1078

65. HR 17 april 2015, ECLI:NL:HR:2015:1075. 
de (appel)rechter in het geding is (wat het geval is als geen memorie van grieven wordt genomen), de sanctie op het niet in acht nemen van de termijnen van het pilotreglement in een redelijke verhouding dient te staan tot het verzuim. Een goede procesorde brengt mee dat het belang van het voorkomen van onredelijke vertraging moet worden afgewogen tegen de ernst van het verzuim en de gevolgen die strikte naleving van het reglement zou hebben voor de procesvoering van de partij die erdoor wordt getroffen. In het te beslissen geval (de termijn voor het indienen van de memorie van grieven was ongebruikt verstreken, terwijl intussen wel in een incident werd doorgeprocedeerd) diende die afweging ertoe te leiden dat een (korte) termijn van veertien dagen werd verleend om het verzuim te herstellen.

Dezelfde regel geldt voor het door het Gerechtshof's-Hertogenbosch gehanteerde pilotreglement. ${ }^{66}$ Hoewel dat reglement wel een (eenmalige) uitstelmogelijkheid kent, geldt ook dan dat het verlenen van een korte termijn om het verzuim om tijdig van grieven te dienen te herstellen (waartoe veertien dagen volstaat), aangewezen is.

Een partij kan aan het verlenen van akte niet-dienen in zijn algemeenheid niet ontkomen door op de datum waarop zij de rechtshandeling waarvan akte niet-dienen is aangezegd, moet verrichten een incident te openen. Dat is alleen anders indien het een incident betreft dat op grond van een bijzondere wettelijke regel eerst en vooraf dient te worden behandeld en beslist of doordat het incident, op grond van de maatstaf van art. $209 \mathrm{Rv}$, eerst en vooraf moet worden behandeld en beslist omdat 'de zaak dat meebrengt'. De Hoge Raad besliste al eens dat deze uitzondering niet geldt voor een wrakingsincident, ${ }^{67}$ niet voor een incident tot schorsing van de procedure, ${ }^{68}$ en ook niet voor een incident tot oproeping van de geëxecuteerde. ${ }^{69} \mathrm{Zij}$ geldt ook niet, zo weten we inmiddels, voor een incidentele vordering tot voeging wegens verknochtheid, ook al wordt op een dergelijke vordering vaak beslist voordat in de hoofdzaak wordt beslist. De hoofdzaak wordt door die vordering niet geschorst, zodat een partijperemptoirstelling of een aanzegging van akte niet-dienen daardoor niet vervalt. ${ }^{70}$ En voor een incidentele vordering op de voet van art. 843a $\mathrm{Rv}$ geldt hetzelfde. ${ }^{71}$ De lijn is volgens A-G Wesseling-van Gent duidelijk: het opwerpen van een incident ontslaat een procespartij nooit van het verrichten van een proceshandeling waarvoor zij peremptoir staat en waarvoor haar akte niet-dienen is aangezegd, tenzij het hof daarvoor uitstel heeft gegeven. ${ }^{72}$ Indien deze akte niet-dienen de memorie van grieven betreft, is dit veelal fataal voor de appellant. Of, in de woorden van

66. HR 17 april 2015, ECLI:NL:HR:2015:1064.

67. HR 24 september 2010, ECLI:NL:HR:2010:BM7671, NJ 2012/513 m.nt. Snijders, JBPr 2011/4 m.nt. Bannier.

68. HR 2 maart 2012, ECLI:NL:HR:2012:BU8176, NJ 2012/158, JBPr 2012/40 m.nt. Van der Veen en Wehrmeijer.

69. HR 13 juli 2012, ECLI:NL:HR:2012:BW4008, NJ 2012/481, JBPr 2012/67 m.nt. Wiersma en Meijer.

70. HR 12 juli 2013, ECLI:NL:HR:2013:BZ5664, NJ 2013/399.

71. HR 21 maart 2014, ECLI:NL:HR:2014:678.

72. ECLI:NL:PHR:2014:47.
Ynzonides en De Boer: de appellant die op de roldatum waartegen peremptoirstelling en aanzegging van akte niet-dienen voor memorie van grieven heeft plaatsgevonden, alleen een incident opwerpt, pleegt - zo voeg ik toe: buiten het uitzonderlijke geval dat sprake is van een incident dat eerst en vooraf moet worden behandeld en beslist - processuele zelfmoord. ${ }^{73}$ Indien de appellant niet van grieven dient, betekent dit immers in zijn algemeenheid dat zijn hoger beroep wordt verworpen of dat hij in zijn hoger beroep niet-ontvankelijk wordt verklaard. Dat is alleen anders indien het hof buiten de grieven om ambtshalve moet toetsen aan de openbare orde of daaraan gelijk te stellen Europeesrechtelijke regels. Daarop kom ik later in deze kroniek terug.

Dit waren niet de enige complicaties die zich in de kroniekperiode ten aanzien van het al dan niet verlenen van akte nietdienen voordeden. Op 15 november 2013 moest de Hoge Raad in twee zaken uitspraak doen waarin akte niet-dienen was verleend nadat sprake was van onttrekking of wisseling van advocaat.

Indien een advocaat zich onttrekt, beëindigt de procesadvocaat zijn advocaatstelling. Indien hij dat doet en zich aan de verdere behandeling van de zaak onttrekt, heeft die beëindiging in het geding pas rechtsgevolg nadat zij ter rolle bekend is gemaakt aan de wederpartij en de rechter. Het geding wordt voortgezet, waarbij de partij al dan niet een nieuwe advocaat stelt. Onttrekking is volgens de Hoge Raad een de cliënt persoonlijk betreffende omstandigheid, zodat het redelijker is dat de cliënt erin voorziet dat hij wederom door een advocaat in het proces wordt vertegenwoordigd dan dat de tegenpartij gedwongen zou zijn tot het doen van nasporingen en het maken van kosten teneinde de procespartij waarvan de advocaat zich heeft onttrokken, te dagvaarden tot hervatting van het rechtsgeding. In het geval van een onttrekking volgt geen schorsing van het geding.

Art. 6.2 LPR bepaalt dat na de onttrekking de zaak wordt verwezen naar de roldatum gelegen op een termijn van twee weken later voor het stellen van een nieuwe advocaat. Art. 6.3 LPR bepaalt vervolgens dat, indien zich een andere advocaat stelt, de proceshandeling waarvoor deze partij staat alsnog op de in art. 6.2 genoemde roldatum wordt verricht en dat daarvan, op schriftelijk verzoek van deze partij, eenmaal een uitstel van vier weken kan worden verleend. Indien zich op de in art. 6.2 LPR genoemde roldatum geen andere advocaat stelt, vervalt het recht van de partij om de proceshandeling waarvoor deze staat, te verrichten.

Indien een advocaat zich aan de zaak onttrekt op de roldatum waarop een partij partijperemptoir staat en waartegen akte niet-dienen is aangezegd, moet de zaak dus worden verwezen naar de rol van twee weken later voor het stellen van een nieuwe advocaat. De beslissing om akte niet-dienen te verlenen wordt daarmee ook twee weken aangehouden (de aan-

73. M. Ynzonides \& M. de Boer, Kroniek burgerlijk procesrecht, NJB 2013/35, p. 145-146. Voor voorbeelden van incidenten die vooraf worden beslist, verwijs ik naar de noot van Van der Veen en Wehrmeijer onder HR 2 maart 2012, ECLI:NL:HR:2012:BU8176, JBPr 2012/40. 
zegging 'verhuist' mee). Op die nieuwe roldatum staat de zaak derhalve nog steeds partijperemptoir, zodat de partij, indien zich voor haar een nieuwe advocaat stelt, op die datum alsnog kan dienen. Het staat het hof niet vrij om dan akte niet-dienen te verlenen en op die grond de memorie te weigeren. ${ }^{74}$ Slechts op grond van bijzondere omstandigheden (art. 1.15 LPR) kan het hof op die roldatum de partij weigeren om de proceshandeling waarvoor zij staat alsnog te verrichten.

Het LPR bevat geen afzonderlijke regeling voor het geval er sprake is van een advocaatwissel, dat wil zeggen dat op dezelfde roldatum waarop een advocaat zich onttrekt, zich een nieuwe advocaat stelt of dat sprake is van herroeping (de partij zelf heeft de opdracht aan de advocaat beëindigd en een nieuwe advocaat voor zich laten stellen). In een dergelijk geval geldt dat indien de opvolgend advocaat uitstel vraagt op de grond dat hij na overname van de behandeling van de zaak nog onvoldoende gelegenheid heeft gehad om de proceshandeling voor te bereiden waarvoor de zaak op de rol stond, in beginsel een uitstel van twee weken moet worden verleend. Dit geldt ook indien tegen de roldatum waarop de advocaatwissel plaatsvindt akte niet-dienen was aangezegd. Een dergelijk uitstelverzoek kan slechts worden afgewezen indien de rechter ambtshalve of naar aanleiding van bezwaren van de wederpartij, waarop de uitstelverzoeker heeft kunnen reageren, aannemelijk acht dat uitstel onverenigbaar is met art. $20 \mathrm{Rv}$ of de eisen van een goede procesorde. Daarvan is onder meer sprake als de rechter aannemelijk acht dat de wisseling van advocaat plaatsvindt om aan de gevraagde akte niet-dienen te ontkomen. De rechter zal de redenen voor zijn afwijzing van het uitstelverzoek uitdrukkelijk moeten vermelden en zijn beslissing daaromtrent moeten motiveren. ${ }^{75}$

Let wel, het voorgaande heeft geen betrekking op het geval dat een advocaat is geschorst of geschrapt van het tableau. Het verlies van hoedanigheid van advocaat, daaronder valt ook een tijdelijk verlies van die hoedanigheid, ${ }^{76}$ heeft tot gevolg dat de procedure op grond van art. $226 \mathrm{lid} 1 \mathrm{Rv}$ van rechtswege is geschorst en dat nadien verrichte rechtshandelingen nietig zijn (art. 226 lid 12 jo. art. 225 lid 3 Rv). Voor een geslaagd beroep op deze nietigheid geldt overigens wel de eis dat degene die dat beroep doet, gemotiveerd stelt dat hij benadeeld is door het feit dat de procedure is stilgelegd en dat hij aldus is getroffen in het belang dat art. $226 \mathrm{Rv}$ beoogt te beschermen. ${ }^{77} \mathrm{Dat}$ nadeel kan zich bijvoorbeeld realiseren doordat een getuigenverhoor doorgang heeft gevonden zonder dat de partij was vertegenwoordigd door een advocaat - en daardoor geen vragen heeft kunnen stellen en geen contra-enquête heeft kunnen vragen - en zij daarna ook niet, door middel van een memorie na enquête, heeft kunnen reageren op hetgeen bij het verhoor is verklaard. ${ }^{78}$ Indien een partij peremptoir staat en er op juiste

74. HR 15 november 2013, ECLI:NL:HR:2013:1259, NJ 2013/574.

75. HR 15 november 2013, ECLI:NL:HR:2013:1245, NJ 2013/573.

76. HR 9 december 2011, ECLI:NL:HR:2011:BT2915, NJ 2012/514 m.nt. Krans.

77. HR 9 december 2011, ECLI:NL:HR:2011:BT2915, NJ 2012/514 m.nt. Krans.

78. HR 24 januari 2014, ECLI:NL:HR:2014:146, NJ 2014/71, JBPr $2014 / 28$ wijze akte niet-dienen is aangezegd, terwijl op de datum dat de proceshandeling moet worden verricht de advocaat zijn hoedanigheid (tijdelijk) heeft verloren, wordt de procedure dus geschorst. In geval van schorsing van de procedure op deze grond beslist de rolraadsheer op het verzoek tot het verlenen van akte niet-dienen op het moment dat de procedure wordt hervat. ${ }^{79}$ In dat geval wordt de zaak dus niet naar de rol verwezen voor het stellen van een nieuwe advocaat en voornoemde uitstelregels die gelden bij onttrekking van een advocaat of een advocaatwissel zijn dan dus niet zonder meer van toepassing.

\section{Grenzen van de rechtsstrijd in hoger beroep}

Het begrip 'grenzen van de rechtsstriid' wordt door de Hoge Raad in verschillende zin gebruikt. ${ }^{80}$ Het wordt allereerst gebruikt in het verband van de toepassing van art. 24, 25 en 149 Rv. De rechtsstrijd van partijen heeft dan - kort gezegd betrekking op hetgeen partijen feitelijk en juridisch aan hun vorderingen en verweren ten grondslag hebben gelegd. Indien een rechter deze grondslag op een verboden wijze aanvult, heet het dat hij is getreden buiten de grenzen van de rechtsstrijd van partijen. Dit deed zich bijvoorbeeld voor in HR 25 januari $2013 .^{81}$ In die zaak had het hof geoordeeld dat sprake was van wederzijdse dwaling, terwijl geen van partijen zich op dat standpunt had gesteld. Ook HR 31 januari 2014, een Arubaanse zaak, vormt daarvan een 'fraai' voorbeeld. ${ }^{82}$ Volgens het Arubaanse procesrecht is de appelrechter ook bevoegd om het bestreden vonnis te vernietigen buiten de (eventueel aangevoerde) grieven om. ${ }^{83}$ Maar dat betekent niet dat de rechter een vordering mag toewijzen op een grondslag die niet door de eisende partij is angevoerd. Spiegelbeeldig geldt natuurlijk hetzelfde; indien een vordering meer grondslagen kent, zal de vordering niet kunnen worden afgewezen zonder dat de rechter al die in de rechtsstrijd betrokken grondslagen kenbaar heeft beoordeeld. ${ }^{84}$ Deze grenzen van de rechtsstrijd dienen ook door de rechter in eerste aanleg te worden gerespecteerd en betreffen dus niet specifiek appelprocesrecht.

Daarnaast hanteert de Hoge Raad ook de term 'grenzen van de rechtsstrijd' als het erom gaat of de rechter in hoger beroep buiten de omvang van het hoger beroep of buiten het door de grieven ontsloten gebied is getreden.

Het bepalen van de omvang van het hoger beroep is een kwestie van uitleg van de appeldagvaarding en de memorie van

79. Zie conclusie A-G Wesseling-van Gent, ECLI:NL:PHR:2013:836, onder 2.9 en HR 24 september 2010, ECLI:NL:HR:2010:BM7671, NJ $2012 / 513$.

80. Zie daarover mijn bijdrage in TCR 2014, afl. 2, p. 45-53: Ambtshalve toetsing in hoger beroep. Over de omvang van het hoger beroep en het door de grieven ontsloten gebied.

81. HR 25 januari 2013, ECLI:NL:HR:2013:BV6689, NJ 2013/200 m.nt. Verstappen.

82. HR 31 januari 2014, ECLI:NL:HR:2014:212, NJ 2014/89.

83. Zie hierover Ras/Hammerstein \& Lewin, De grenzen van de rechtsstrijd in hoger beroep in burgerlijke zaken in de Nederlandse Antillen en Aruba, Deventer: Kluwer 2008 en G.C.C. Lewin, Het hoger beroep en het cassatieberoep in burgerlijke zaken in de Nederlandse Antillen en Aruba, Deventer: Kluwer 2009.

84. HR 1 februari 2013, ECLI:NL:HR:2013:BX9761. 
grieven, waarbij beslissend is wat de andere partij redelijkerwijs had moeten begrijpen. ${ }^{85}$ Dat de rechter bij die uitleg niet al te bekrompen moet zijn, wisten we al, maar is in de kroniekperiode weer eens bevestigd. ${ }^{86}$ Het gaat niet alleen om de bewoordingen van de petita in de appeldagvaarding en de memorie van grieven zelf, maar ook om hetgeen over die petita in het lichaam van de dagvaarding of de memorie van grieven is gezegd. De appellant was vergeten om zijn petitum in hoger beroep aan te passen aan zijn in eerste aanleg gedane eiswijziging. Voor de Hoge Raad bleek uit de memorie van grieven duidelijk genoeg dat de vordering in hoger beroep mede deze eiswijziging omvatte. Bij die uitleg speelde een rol dat de appellant bij memorie van grieven uitdrukkelijk zijn in eerste aanleg naar voren gebrachte stellingen had gehandhaafd. De geïntimeerde had bij memorie van antwoord ook ten aanzien van de eiswijziging verweer gevoerd (dat zij dit subsidiair had gedaan, was volgens de Hoge Raad niet van belang) en was dan ook niet in haar verdediging geschaad. Dat de appellant zijn onduidelijke petitum in hoger beroep bij gelegenheid van het (schriftelijk) pleidooi niet met zoveel woorden had verduidelijkt, maakte het voor de Hoge Raad niet anders.

Voor de appellant gunstige beslissingen vallen buiten de omvang van het hoger beroep. Indien geen sprake is van incidenteel hoger beroep, mag de appellant van het hoger beroep niet slechter worden (het verbod van reformatio in peius). Indien het hof in strijd met dit verbod een beslissing neemt, treedt het buiten de omvang van het hoger beroep of, in de woorden van de Hoge Raad, buiten de grenzen van de rechtsstrijd in hoger beroep. ${ }^{87}$

De omvang van het hoger beroep moet worden onderscheiden van het door de grieven ontsloten gebied. Binnen de omvang van het hoger beroep wordt de beoordelingsruimte van de appelrechter verder beperkt door de grieven. ${ }^{88}$ Slechts voor zover (eind)beslissingen van de eerste rechter die ten nadele van de appellant strekken met grieven worden bestreden, kan de appelrechter het geschil opnieuw beoordelen. Daarover ging het in HR 1 februari $2013 .{ }^{89}$ De rechtbank had in het kader van een beroep op dwaling geoordeeld dat er door de latere appellant een bewust onjuiste mededeling was gedaan en dat het er niet aan afdeed dat deze onjuiste mededeling niet aan de wederpartij maar aan een derde was gedaan, omdat te voorzien was dat deze mededeling wel de wederpartij zou bereiken. De appellant richtte in hoger beroep diverse klachten tegen deze overweging, maar richtte geen grief tegen het oordeel van de rechtbank dat aan een geslaagd beroep op dwaling niet in de weg staat dat de mededeling niet aan de wederpartij zelf is gedaan. Door onder meer toch te oordelen dat de onjuiste informatie aan de derde niet tot vernietiging wegens dwaling kon leiden, was het hof buiten het door de grieven

85. HR 16 december 2011, ECLI:NL:HR:2011:BT7494.

86. HR 24 januari 2014, ECLI:NL:HR:2014:151, JBPr 2014/27 m.nt. Lewin.

87. HR 6 september 2013, ECLI:NL:HR:2013:CA1726.

88. Zie over het begrip 'grieven' de noot van G.C.C. Lewin onder HR 27 juni 2014, ECLI:NL:HR:2014:1557, JBPr 2014/39.

89. ECLI:NL:HR:2013:BY3129, NJ 2013/84, JOR 2013/160 m.nt. Ernste. ontsloten gebied - of, opnieuw in de woorden van de Hoge Raad: buiten de grenzen van de rechtsstrijd in hoger beroep getreden.

Ook de vaststelling van een vaststaand feit door de rechtbank is een eindbeslissing. ${ }^{90}$ Indien deze beslissing mede dragend is voor een in het nadeel van de appellant uitgevallen beslissing en deze tegen de vaststelling van dat feit geen grief richt, dan is het hof aan die vaststelling gebonden. ${ }^{91}$ Indien het hof dat niet doet, miskent het niet alleen de grenzen van het door de grieven ontsloten gebied, maar miskent het, in het kielzog daarvan, ook dat het de rechter op grond van art. 24 en $149 \mathrm{Rv}$ niet vrijstaat om ambtshalve de juistheid van feiten die tussen partijen vaststaan, aan de orde te stellen en daarover anders te beslissen..$^{92}$

De vraag of het hof buiten de grenzen van de rechtsstrijd in hoger beroep was getreden, deed zich ook voor in HR 8 februari $2013 .{ }^{93}$ In die zaak moest het hof oordelen over het saldo van een vordering, terwijl het daartoe over onvoldoende duidelijke gegevens beschikte. Het hof overwoog dat partijen het debat daarover nog niet gevoerd hadden op grond van een overzichtelijke en eenduidige specificatie. Dat had het hof tot het oordeel kunnen brengen dat de vordering onvoldoende (duidelijk) was onderbouwd, maar het hof was welwillender. Het stelde de eisende partij in de gelegenheid alsnog een duidelijk financieel overzicht in het geding te brengen. Het hof overwoog daarbij dat partijen voor een efficiënt verloop van het verdere debat in hoger beroep al hun stellingen en al hun weren in de nog te nemen memorie dienden te vermelden en dat het hof, omwille van een overzichtelijke verdere behandeling, geen stellingen of weren van partijen uit eerdere processtukken in zijn oordeel zou betrekken. Met andere woorden: we beginnen van voren af aan en vergeten wat er is gebeurd. Deze inventieve en actieve stap vond genade in de ogen van de Hoge Raad: geen rechtsregel verplicht het hof immers om de zaak te onderzoeken en te beslissen op de grondslag van stellen en weren die onvoldoende overzichtelijk en duidelijk zijn. Of, zoals de A-G het verwoordde: de door het hof aangegeven weg is doelmatig, zinvol en bij uitstek geëigend om de partijen het hun in processueel opzicht toekomende te bieden en het schept de rechter een heilzame duidelijkheid. En kennelijk - de Hoge Raad zegt daar niets over - verzet ook de tweeconclusieregel (zie hierna) zich hier niet tegen. Maar, en daarop ging het toch nog mis, dan moet het hof zich ook aan zijn woord houden en inderdaad bij de beoordeling of een partij haar standpunt voldoende heeft onderbouwd, niet het standpunt dat de andere partij vóór het tussenarrest heeft ingenomen, betrekken. Dat had het hof wel gedaan en daarmee was het buiten de door het hof zelf zo duidelijk getrokken grenzen van de rechtsstrijd getreden.

90. Zie o.a. HR 5 september 2003, ECLI:NL:HR:2003:AF7897, NJ $2004 / 583$.

91. HR 17 januari 2014, ECLI:NL:HR:2014:92, NJ 2014/223 m.nt. Perrick.

92. Zie o.a. HR 20 november 2009, ECLI:NL:HR:2009:BJ8340, RvdW $2009 / 1363$.

93. ECLI:NL:HR:2013:BY2581, NJ 2013/103 


\section{Devolutieve werking}

Het zou gesneden koek moeten zijn voor elke appelrechter: een geïntimeerde wordt beschermd indien hij niet opkomt tegen een voor hem ongunstige eindbeslissing die niet heeft geleid tot een voor hem ongunstig dictum. ${ }^{94}$ In een dergelijk geval komen zijn verworpen of niet-behandelde stellingen en weren ambtshalve aan de orde indien de appelrechter een van de grieven van appellant gegrond acht. Dit wordt de positieve zijde van de devolutieve werking van het hoger beroep genoemd. ${ }^{95}$ Toch wordt er nog wel eens een in eerste aanleg door geïntimeerde gevoerd verweer over het hoofd gezien, ook weer in deze kroniekperiode. ${ }^{96}$

De devolutieve werking strekt zich ook uit tot het door een geïntimeerde in eerste aanleg gedaan bewijsaanbod. Indien de geïntimeerde in eerste aanleg in het gelijk is gesteld zonder dat aan bewijslevering is toegekomen, dient de appelrechter, indien één of meer grieven van appellant gegrond blijken te zijn, alsnog het in eerste aanleg gedane bewijsaanbod van geïntimeerde te behandelen. ${ }^{97}$ Dit geldt dus in theorie ook indien de geïntimeerde in hoger beroep verstek laat gaan. Het lijkt evenwel weinig zinvol om, ook al is het in eerste aanleg gedane bewijsaanbod ter zake dienend en voldoende concreet en specifiek, in hoger beroep alsnog een bewijsopdracht te verstrekken aan een partij die niet is verschenen.

\section{De twee-conclusieregel}

De appellant moet in zijn eerste inhoudelijke processtuk al zijn stellingen (grieven) neerleggen die zouden moeten leiden tot vernietiging van de bestreden uitspraak. ${ }^{98}$ Dat geldt ook in hoger beroep van een kort geding. ${ }^{99}$ Een wijziging van de (grondslag van de) eis bij pleidooi is dus niet meer toelaatbaar, tenzij zich een van de in de rechtspraak erkende uitzonderingen voordoet. ${ }^{100}$ Ook wijzigingen en vermeerderingen van de eis of de grondslag daarvan door de appellant gelden als een grief. Of een betoog als een nieuwe grief moet worden aangemerkt of als een uitwerking van eerdere stellingen, is een kwestie van uitleg van de gedingstukken. ${ }^{101}$

Hetzelfde geldt in beginsel voor de verweren die door de geïntimeerde worden aangevoerd tegen de vordering van de oorspronkelijk eiser. Uitbreiding daarvan dient eveneens plaats te vinden in de eerste conclusie in hoger beroep. De bevoegdheid om in hoger beroep nieuwe verweren te voeren, is dus in beginsel beperkt tot het eerste processtuk dat partijen in hoger beroep nemen. Maar wat geldt als eerste conclusie indien er ook sprake is van een incidenteel hoger beroep? Deze

94. Zie o.a. Snijders/Wendels 2009/219, Asser/Bakels, Hammerstein \& Wesseling-van Gent 2012/133 en Ras/Hammerstein 2011/74 e.v.

95. In de vorige kroniek is dit thema uitgebreider aan bod gekomen.

96. HR 31 januari 2014, ECLI:NL:HR:2014:214, JBPr 2014/29 m.nt. G. van Rijssen; HR 20 juni 2014, ECLI:NL:HR:2014:1492, NJ 2014/335; HR 3 april 2015, ECLI:NL:HR:2015:838.

97. HR 21 juni 2013, ECLI:NL:HR:2013:BZ5360.

98. Zie B.T.M. van der Wiel, De in beginsel strakke regel, TCR 2012, afl. 3, p. 71 e.v.

99. HR 14 juni 2013, ECLI:NL:HR:2013:BZ4163, NJ 2013/341.

100. Vgl. HR 20 juni 2008, ECLI:NL:HR:2008:BC4959, NJ 2009/21 en HR 19 juni 2009, ECLI:NL:HR:2009:BI8771, NJ 2010/154.

101. Zie bijv. HR 21 juni 2013, ECLI:NL:HR:2013:BZ8363. vraag kwam aan de orde in HR 8 februari 2013 (Van Gaalen/ LTO Noord), ${ }^{102}$ en het antwoord dat de Hoge Raad op die vraag geeft, lijkt logisch. Het incidenteel hoger beroep neemt een zelfstandige positie in ten opzichte van het principaal hoger beroep. ${ }^{103}$ En dat geldt ook voor de bepaling of een stuk een eerste processtuk is. De geïntimeerde in het incidenteel hoger beroep mag dus nog bij memorie van antwoord in incidenteel hoger beroep nieuwe verweren aanvoeren. Maar die nieuwe verweren kunnen dus niet tegelijkertijd ook gelden als grieven in het principaal hoger beroep, want daarvoor zijn ze te laat aangevoerd. Dit kan tot gevolg hebben dat in principaal en incidenteel hoger beroep (deels) tegenstrijdige beslissingen worden genomen, die beide gezag van gewijsde kunnen krijgen. Dat deze - in de woorden van annotator Snijders: loepzuivere - toepassing van het appelprocesrecht tot tegenstrijdige uitspraken van dezelfde rechter over dezelfde rechtsverhouding kan leiden, hebben we kennelijk wel voor lief te nemen en is voor de Hoge Raad geen reden om op de tweeconclusieregel een uitzondering te aanvaarden. Dat verdraagt zich moeizaam met de pogingen die de Hoge Raad in het in de vorige kroniek al besproken arrest Fafiani/KSN juist deed om tegenstrijdige uitspraken met elk hun eigen gezag van gewijsde te voorkomen. ${ }^{104}$ Toen overwoog de Hoge Raad nog dat onbeperkte toepassing van de hoofdregel van de devolutieve werking tot gevolg zou kunnen hebben dat de appelrechter over hetzelfde geschilpunt een ander oordeel bereikt dan de eerste rechter, zodat na het in kracht van gewijsde gaan van de uitspraak van de appelrechter met betrekking tot dat geschilpunt twee tegenstrijdige onherroepelijke rechterlijke uitspraken met gezag van gewijsde zouden bestaan. Om die reden formuleerde de Hoge Raad een - inmiddels van meerdere kanten bekritiseerde - uitzondering op de positieve zijde van devolutieve werking. ${ }^{105}$

De aard van het geschil kan meebrengen dat de appelrechter in bepaalde zaken ook rekening mag (en in beginsel moet) houden met grieven of verweren die na het verzoek- of verweerschrift worden aangevoerd, omdat partijen er belang bij hebben dat de uitspraak berust op een juiste en volledige waardering van de van belang zijnde omstandigheden ten tijde van de uitspraak in hoger beroep. Deze uitzondering is bijvoorbeeld aanvaard voor beslissingen ter zake van alimentatie en ter zake van omgangsregelingen. ${ }^{106}$ De uitzondering lijkt ook te gelden in een procedure tot faillietverklaring; ook dan dient de rechter zijn beslissing te baseren op de toestand ten tijde van zijn uitspraak. In HR 3 mei 2013 had de verweerster na de

102. ECLI:NL:HR:2013:BY6699, JBPr 2013/17 m.nt. Van der Wiel, NJ 2014/175 m.nt. Snijders.

103. Vgl. HR 18 februari 1994, ECLI:NL:HR:1994:ZC1274, NJ 1994/606 m.nt. Ras.

104. HR 30 maart 2012, ECLI:NL:HR:2012:BU8514, JBPr 2012/42 m.nt. Lewin, NJ 2012/583 m.nt. Krans.

105. Zie bijv. A.C. van Schaick, Tegenstrijdige beslissingen, NTBR 2013/1; B.T.M. van der Wiel in zijn noot onder Van Gaalen/LTO Noord in JBPr 2013/17 en Van der Wiel 2013.

106. HR 28 september 2012, ECLI:NL:HR:2012:BW9226, NJ 2012/552 en HR 20 maart 2009, ECLI:NL:HR:2009:BG9917, NJ 2010/153 m.nt. H.J. Snijders. Zie hierover ook de kroniek 'Familieprocesrecht' in dit nummer. 
mondelinge behandeling in hoger beroep een fax aan het hof gezonden met een verklaring waaruit bleek dat de door de aanvrager aangedragen steunvordering integraal was voldaan. ${ }^{107}$ De Hoge Raad oordeelde dat het hof, ook al was het onderzoek al gesloten, deze fax niet terzijde mocht leggen, maar had moeten opvatten als een verzoek tot heropening van de behandeling. Dat heeft natuurlijk alleen zin als bij een eventueel heropende behandeling dit nieuwe verweer alsnog in de rechtsstrijd kon worden betrokken. Ik leid hieruit af dat de twee-conclusieregel er niet aan in de weg staat dat tijdens de mondelinge behandeling dit nieuwe verweer zou worden gevoerd. Dit geldt temeer nu het hier een nieuw feit betrof. Ter zake daarvan was al eerder beslist dat grieven (en hetzelfde geldt voor verweren) na het eerste inhoudelijke processtuk in het algemeen toelaatbaar kunnen zijn indien daarmee aanpassing wordt beoogd aan eerst na dat tijdstip voorgevallen of gebleken feiten. ${ }^{108}$

\section{Ambtshalve toetsing in hoger beroep}

Het arrest Heesakkers/Voets, over de ambtshalve toetsing in hoger beroep, heeft veel stof doen opwaaien en pennen in beweging gezet. ${ }^{109}$ Toch is het voor wat het appelprocesrecht betreft minder baanbrekend dan het misschien lijkt. ${ }^{110}$

In het arrest Asbeek Brusse en De Man Garabito heeft het Hof van Justitie van de Europese Unie geoordeeld dat de nationale rechter, wanneer hij op grond van de nationale regels van procesrecht bevoegd is ambtshalve de geldigheid van een rechtshandeling te toetsen aan nationale regels van openbare orde, deze bevoegdheid ook moet uitoefenen om ambtshalve te beoordelen of een onder de richtlijn oneerlijke bedingen in consumentenovereenkomsten (Richtlijn 93/13) vallend contractueel beding uit het oogpunt van de daarin gegeven criteria mogelijk oneerlijk is. ${ }^{111}$ Het is staande jurisprudentie dat de appelrechter gehouden is om ambtshalve te toetsen aan regels van openbare orde, ${ }^{112}$ ook indien op dat punt, of in het geheel, geen grieven zijn aangevoerd. Zo zijn regels van internationale bevoegdheid van openbare orde en is de rechter dan ook ambtshalve gehouden te onderzoeken of hem rechtsmacht toekomt, ook als partijen zich daarover niet hebben uitgelaten en de grieven daarop geen betrekking hebben. ${ }^{113}$ Daarbij is de appelrechter wel gebonden aan de omvang van het hoger beroep; buiten die omvang mag hij niet

107. ECLI:NL:HR:2013:BZ1058, NJ 2013/275.

108. HR 19 juni 2009, ECLI:NL:HR:2009:BI8771, NJ 2010/154 m.nt. Snijders, JBPr 2009/39 m.nt. Van der Wiel.

109. HR 13 september 2013, ECLI:NL:HR:2013:691, JBPr 2014/2 m.nt. F.J.H. Hovens, NJ 2014/274 m.nt. Krans. Zie over dit arrest o.a. (Heesakkers/Voets), WPNR (2013) 6996; , afl. 12, p. 329-339; R.M.M. de Moor en M.B.M. Loos in hun annotatie bij Heesakkers/Voets in TvC 2013, afl. 6, p. 268 e.v.

110. Voor een uitgebreide bespreking van dit arrest verwijs ik naar mijn eerdergenoemde artikel: Ambtshalve toetsing in hoger beroep, over de omvang van het hoger beroep en het door de grieven ontsloten gebied, TCR 2014, afl. 2, p. 45 e.v.

111. HvJ EU 30 mei 2013, C-488/11, NJ 2013/487 m.nt. Mok.

112. HR 17 december 1925, NJ 1926, p. 193 en HR 15 juni 1934, NJ 1934, p. 1297 m.nt. PS. Zie ook Snijders/Wendels 2009/165.

113. HR 17 april 2015, ECLI:NL:HR:2015:1077. toetsen, ook niet als het om bepalingen van openbare orde gaat. $^{114}$

In lijn daarmee heeft de Hoge Raad geoordeeld dat de appelrechter binnen de omvang van het hoger beroep (door de Hoge Raad in het hier besproken arrest aangeduid als: de grenzen van de rechtsstrijd van partijen) ook buiten het door de grieven ontsloten gebied, en ook als er in het geheel niet van grieven is gediend, ambtshalve zal moeten toetsen aan Richtlijn 93/13. Deze ambtshalve toetsing zal ook moeten plaatsvinden aan andere consumentenbeschermende richtlijnen die normen bevatten die gelijkwaardig zijn aan regels van openbare orde. ${ }^{15}$ Dit geldt zowel voor de zaken waarin in het geheel niet van grieven is gediend, als voor de zaken waarin wel van grieven is gediend, maar er geen grieven gericht zijn tegen beslissingen die een dergelijke strijdigheid zouden kunnen bevatten. Indien hij over de daartoe noodzakelijke gegevens, feitelijk en rechtens, beschikt om te vermoeden dat zich in de zaak een dergelijke strijdigheid voordoet, zal de rechter daarnaar onderzoek moeten doen, ook indien daarop gerichte stellingen niet aan de vorderingen of het verweer ten grondslag zijn gelegd, en ook indien de grieven daarop geen betrekking hebben. Zo nodig zal de rechter instructiemaatregelen moeten nemen om alle relevante feiten te kunnen vaststellen.

\section{Terugwijzingsverbod}

Inmiddels is duidelijk dat de zwaluw van HR 11 december 2009 nog geen zomer heeft gemakt. ${ }^{116}$ Waar de Hoge Raad oordeelde dat ook in een geval waarin in eerste aanleg ten onrechte ontslag van instantie is verleend, en waarin dus de rechter op louter processuele gronden niet aan een inhoudelijke beoordeling van de zaak tussen de betrokken partijen is toegekomen, de appelrechter de zaak mag (en ook moet) terugwijzen naar de rechter in eerste aanleg, leefde bij velen de hoop dat daarmee aan het recht op een inhoudelijke behandeling in twee feitelijke instanties op grotere schaal toepassing zou kunnen worden gegeven. De Hoge Raad leek een nieuw criterium te hebben geformuleerd voor het maken van een uitzondering op het terugwijzingsverbod. Niet alleen in zaken waarin de eerste rechter zich ten onrechte onbevoegd heeft verklaard, maar in alle zaken waarin de eerste rechter op louter processuele gronden niet aan een inhoudelijke beoordeling van de zaak tussen de betrokken partijen is toegekomen, zou de appelrechter mogen terugwijzen. ${ }^{117}$ Het bleek te vroeg gejuicht.

Op 17 januari 2014 deed de Hoge Raad uitspraak in twee schuldsaneringszaken waarin de vraag speelde of het hof de zaak zelf inhoudelijk moest afdoen of dat het de zaak terug mocht wijzen naar de rechtbank voor een inhoudelijke behandeling. In het ene geval had de rechtbank een omzettingsver-

114. In gelijke zin: Ras/Hammerstein 2011/56, laatste alinea; Snijders lijkt het anders te zien: Snijders/Wendels 2009/236.

115. Zie voor een opsomming van consumentenbeschermende richtlijnen die dergelijke normen (kunnen) bevatten, voetnoot 21 van de annotatie van M.B.M. Loos in TvC 2013, afl. 6, p. 268; zie ook Ancery 2013, p. 331.

116. HR 11 december 2009, ECLI:NL:HR:2009:BK0857, JBPr 2010/17 m.nt. D. Roffel, NJ 2010/581 m.nt. H.J. Snijders.

117. Zie bijv. conclusie A-G Strikwerda voor HR 8 juli 2011, ECLI:NL:HR: 2011:BQ5083. 
zoek ex art. 15b van de Faillissementswet afgewezen omdat de schuldenaar het verzoek niet tijdig had ingediend. ${ }^{118}$ In het andere geval had de rechtbank het verzoek van de schuldenaar om tot de wettelijke schuldsaneringsregeling te worden toegelaten niet-ontvankelijk verklaard omdat de schuldenaar inmiddels in staat van faillissement was verklaard en zijn verzoek niet kon worden aangemerkt als een omzettingsverzoek. ${ }^{119}$ In beide gevallen beoordeelde het hof de zaak inhoudelijk, terwijl toch verdedigbaar is dat de rechtbank in beide gevallen op louter processuele gronden niet tot een inhoudelijke behandeling van het omzettings- dan wel schuldsaneringsverzoek is gekomen. De daartegen gerichte klachten faalden evenwel. De Hoge Raad overweegt dat het hoger beroep was gericht tegen een einduitspraak en dat zich geen van de in het arrest van 11 december 2009 genoemde uitzonderingen voordeed. Het hof diende daarom de zaak aan zich te houden. Kennelijk moeten de uitzonderingen van 11 december 2009 dus beperkt worden opgevat en zien die alleen op de vernietiging van een onbevoegdheidsverklaring zoals hiervoor benoemd en op een vernietiging van een ten onrechte door de eerste rechter verleend ontslag van instantie. Meer ruimte wil de Hoge Raad de appelrechter niet geven om de zaak inhoudelijk in twee feitelijke instanties te laten beslissen. In alle andere gevallen, ook al is er sprake van dat de eerste rechter op louter processuele gronden niet aan een inhoudelijke behandeling is toegekomen, is terugwijzing naar de eerste rechter niet aan de orde. Snijders ziet in zijn noot overigens nog wel wat ruimte in de arresten van de Hoge Raad, omdat in beide zaken de nietontvankelijkheidsbeslissingen gronden 'met een zekere materieelrechtelijke lading' hadden.

Waar een door het hof vernietigd vonnis deels een tussenvonnis en deels een eindvonnis is (een zogenoemd deelvonnis dus), geldt evenzeer het terugwijzingsverbod; het hof moest in dat geval de zaak zelf afdoen. ${ }^{120}$

\section{Pleidooi}

De lijn van de Hoge Raad is duidelijk: alleen in zeer uitzonderlijke gevallen mag een verzoek om de zaak te mogen bepleiten worden afgewezen. ${ }^{121}$ Ook de omstandigheid dat het verzoek om pleidooi kennelijk alleen is gedaan om een verzuim om tijdig een memorie in te dienen te herstellen, doet aan het recht op pleidooi niet af. ${ }^{122}$ Toch is aan de serie arresten over geweigerde pleidooien ${ }^{123}$ weer een aantal exemplaren toegevoegd.

Nadat geïntimeerde ter rolle van 21 december 2010 haar memorie van antwoord had genomen, heeft appellante op

118. HR 17 januari 2014, ECLI:NL:HR:2014:97, NJ 2015/68 m.nt. Snijders.

119. HR 17 januari 2014, ECLI:NL:HR:2014:96, JBPr 2014/26 m.nt. Roffel.

120. HR 7 februari 2014, ECLI:NL:HR:2014:260, JOR 2014/92 m.nt. Bakker.

121. In de kroniekperiode onder meer herhaald in HR 3 mei 2013 , ECLI:NL:HR:2013:BZ2867.

122. Vgl. HR 15 maart 1996, ECLI:NL:HR:1996:ZC2013, NJ 1997/341 m.nt. H.J. Snijders, waarin het feit dat de termijn voor het indienen van een memorie van antwoord onbenut was verstreken, geen (beslissende) afbreuk deed aan het recht op pleidooi.

123. Zie de vorige kroniek 'Hoger beroep’.
4 januari 2011 vier weken voor akte gevraagd, hetgeen is toegestaan. Op 1 februari 2011 nam appellante evenwel geen akte, maar heeft ze pleidooi gevraagd. Dit werd haar door de rolraadsheer geweigerd met de redenering dat een partij, indien de zaak op grond van art. 2.14 LPR voor beraad staat, ofwel om akte ofwel om pleidooi ofwel om arrest kan vragen. $\mathrm{Nu}$ er om akte was gevraagd, maar de gelegenheid daartoe onbenut was gebleven, kon niet alsnog om pleidooi worden gevraagd. De Hoge Raad heeft er weinig woorden voor nodig om de tegen deze weigering gerichte klacht te laten slagen, en verwijst kortheidshalve naar de conclusie van de A-G, die de vaste lijn herhaalt. ${ }^{124}$ Niets nieuws onder de zon dus.

Dat er niet alleen een recht op pleidooi bestaat, maar ook een recht voor partijen om zich uit te laten over de vraag of zij pleidooi wensen, is ook vaste jurisprudentie. ${ }^{125}$ Toch ging het ook in deze kroniekperiode op dat punt weer mis en moest de Hoge Raad eraan te pas komen om een arrest dat was gewezen zonder dat partijen (in de hoofdzaak) een reële mogelijkheid hadden gehad om pleidooi te vragen, te redresseren. ${ }^{126}$ Partijen mogen niet worden verrast door een einduitspraak zonder dat die mogelijkheid is geboden. Hoe ver zich dit uitstrekt, is overigens nog niet helemaal duidelijk. Het LPR (art. 2.24) voorziet alleen in een mogelijkheid tot beraad voor het vragen van pleidooi na de eerste conclusiewisseling. Partijen kunnen ook na, om maar iets te noemen, akte niet-dienen, aktewisseling, tussenarrest of (memories na) bewijslevering behoefte hebben aan pleidooi. De huidige rolpraktijk is dat in die fases van de procedure de zaak direct voor (het fourneren van stukken voor) arrest wordt geplaatst, zonder dat uitdrukkelijk gelegenheid voor het vragen van pleidooi wordt gegeven. Volgens A-G Wesseling-van Gent ligt in die gevallen het initiatief bij partijen om een verzoek tot pleidooi te doen en is het hof niet verplicht om partijen ambtshalve in de gelegenheid te stellen zich uit te laten over de wenselijkheid van pleidooi. ${ }^{127}$

Indien een verzoek om pleidooi wordt afgewezen omdat het te laat is gedaan, kunnen partijen het hof verzoeken alsnog pleidooi toe te staan. Het LPR biedt daarvoor uitdrukkelijk de gelegenheid. In art. 4.5 LPR is bepaald dat een niet-tijdig verzoek om pleidooi kan worden ingewilligd, indien schriftelijk wordt toegelicht waarom het verzoek niet eerder is gedaan. Als partijen van die gelegenheid geen gebruik maken, kunnen zij niet in cassatie met succes erover klagen dat hun recht op pleidooi is geschonden. ${ }^{128}$

Het LPR geeft partijen de gelegenheid om - als beide partijen daarmee instemmen - in plaats van mondeling pleidooi de zaak door het indienen van pleitnotities schriftelijk te bepleiten (art. 5.5 LPR). In een zaak waarin partijen hadden gekozen voor schriftelijk pleidooi, diende een van partijen een

124. HR 22 februari 2013, ECLI:NL:HR:2013:BY4124, JBPr 2013/29 m.nt. Wiersma.

125. HR 10 juni 2011, ECLI:NL:HR:2011:BP9038, JBPr 2011/49 m.nt. W.I. Wisman, NJ 2011/272 en HR 16 november 2012, ECLI:NL:HR: 2012:BX7886.

126. HR 21 november 2014, ECLI:NL:HR:2014:3352.

127. ECLI:NL:PHR:2014:1858.

128. Zie conclusie A-G Wesseling-van Gent voor HR 4 juli 2013, ECLI:NL:PHR:2013:CA0015 (art. 81 lid 1 Wet RO). 
pleitnota in van 72 pagina's. Dat ging niet alleen de wederpartij - die bezwaar maakte - maar ook het hof te ver. Het overwoog dat een pleidooi in het algemeen (slechts) tot doel heeft de reeds door een partij ingenomen standpunten toe te lichten en te verduidelijken. De toegestane lengte van de spreektijd in geval van mondeling pleidooi (30 minuten) impliceert dat de pleitnota van beperkte omvang dient te zijn om binnen de beschikbare spreektijd te kunnen voordragen. Ook de pleitnota bij schriftelijk pleidooi moet daarom, aldus het hof, van beperkte omvang zijn. Het hof liet de pleitnota van 72 pagina's om die reden buiten beschouwing. De Hoge Raad ziet dat anders. ${ }^{129}$ Het hof had de omvang van de pleitnotities niet vooraf aan een maximale omvang gebonden en ook het LPR schrijft geen maximale omvang van de pleitnotities voor. De spreektijd voor het mondeling pleidooi kan, aldus de Hoge Raad, niet dienen als maatstaf voor de omvang van pleitnotities bij schriftelijk pleidooi, omdat aan die maximale spreektijd (ook) organisatorische overwegingen ten grondslag liggen, die niet gelden bij een uitsluitend schriftelijke gedachtewisseling. Door de pleitnota buiten beschouwing te laten enkel omdat deze, indien voorgelezen, niet zou voldoen aan de maatstaven die zouden gelden bij een mondeling pleidooi, was het hof uitgegaan van een onjuiste rechtsopvatting. Het arrest lijkt wel ruimte te bieden om schriftelijke pleitnotities aan een maximale omvang te binden, maar dat moet dan wel vooraf kenbaar zijn gemaakt.

In het Voorstel tot wijziging van het Wetboek van Burgerlijke Rechtsvordering in verband met vereenvoudiging en digitalisering van het procesrecht, onderdeel van het programma Kwaliteit en Innovatie (KEI), ${ }^{130}$ wordt het recht op pleidooi afgeschaft; art. $134 \mathrm{Rv}$ vervalt. Daar staat tegenover dat naar de bedoeling van de minister zowel in eerste aanleg als in hoger beroep de mondelinge behandeling centraal komt te staan. Blijkens de toelichting is bij de voorbereiding van het wetsvoorstel gebleken dat een verplichting om in hoger beroep altijd een mondelinge behandeling te houden niet opportuun is, omdat tijdens de procedure in eerste aanleg veelal reeds een mondelinge behandeling zal hebben plaatsgevonden en de feiten in hoger beroep voldoende vaststaan. ${ }^{131}$ In hoger beroep moet daarom gaan gelden dat een mondelinge behandeling plaatsvindt indien de rechter daartoe aanleiding ziet of indien een van partijen, nadat zij zijn gewezen op hun recht te worden gehoord, binnen een door de rechter gestelde redelijke termijn heeft verklaard dat zij gebruik wil maken van dit recht (art. $354 \mathrm{Rv}$-nieuw). In hoeverre de appelrechters van deze mogelijkheid gebruik zullen gaan maken, zal de toekomst moeten leren. De minister heeft er vertrouwen in dat de rechter in zowel vorderings- als verzoekprocedures zorgvuldig zal afwegen of er aanleiding is om een mondelinge behandeling te

129. HR 19 april 2013, ECLI:NL:HR:2013:BZ2904, NJ 2013/240, JBPr 2013/40 m.nt. Van Rijssen.

130. Kamerstukken II 2014/15, 34059, 2 (wetsvoorstel) en 3 (MvT). Inmiddels is de nota van wijziging bij de Tweede Kamer ingediend (9 april 2015).

131. Zie <www.rijksoverheid.nl/documenten-en-publicaties/publicaties/ 2014/04/17/concept-memorie-van-toelichting-wijziging-wetboek-vanburgerlijke-rechtsvordering-voor-digitalisering-procesrecht.html>. houden en dat daarnaast partijen behoorlijk worden geïnformeerd over het recht te worden gehoord. ${ }^{132}$

\section{Proceskosten}

Volgens vaste jurisprudentie is een proceskostenveroordeling nog steeds voldoende belang voor hoger beroep. ${ }^{133}$ Een beslissing over de proceskosten moet zo nodig ambtshalve worden uitgesproken, ${ }^{134}$ en de appelrechter heeft zo nodig ambtshalve te oordelen over de kosten van het geding, ook die van eerste aanleg. Een grief is daarvoor niet noodzakelijk. ${ }^{135}$ De appelrechter is dus niet gebonden aan, of afhankelijk van, door partijen aangevoerde grieven tegen een in eerste aanleg al dan niet uitgesproken proceskostenveroordeling. Na verwijzing kan dat anders zijn. Het hof dat na verwijzing door de Hoge Raad moet beslissen, is gebonden aan de beslissingen die in cassatie niet of tevergeefs zijn aangevochten. Indien de vóór cassatie uitgesproken beslissing omtrent de proceskosten niet voortbouwt op of onlosmakelijk samenhangt met een beslissing waarover in cassatie met succes is geklaagd, is de verwijzingsrechter aan die beslissing gebonden. ${ }^{136}$

$\mathrm{Bij}$ de beoordeling van de proceskostenveroordeling in eerste aanleg mag de appelrechter betrekken in hoeverre een verweer dat in hoger beroep slaagt, niet reeds in eerste aanleg gevoerd had kunnen worden. De 'nodeloze kosten'-regeling van de laatste volzin van art. 237 lid $1 \mathrm{Rv}$ (dat volgens art. 353 lid $1 \mathrm{Rv}$ ook in hoger beroep geldt) geeft de feitenrechter een discretionaire bevoegdheid, ${ }^{137}$ en biedt de appelrechter de ruimte om de kosten van de eerste aanleg voor rekening te laten van de partij die zonder goede grond pas in hoger beroep een slagend verweer aanvoert. ${ }^{138}$

De Hoge Raad heeft herhaald dat er geen grond bestaat voor het doorschuiven van de proceskosten in een vrijwaringszaak naar de hoofdzaak. De afwijzing van de vorderingen in de hoofdzaak kan dan ook niet leiden tot een veroordeling in de proceskosten van de vrijwaringszaak. ${ }^{139}$

\section{Literatuur en wetgeving}

De in de kroniekperiode verschenen literatuur en voor het appelprocesrecht relevante op handen zijnde wetgeving zijn in de loop van deze kroniek al de revue gepasseerd.

Een uitgebreide bespreking van de veranderingen die het al genoemde voorstel tot wijziging van het $\mathrm{Rv}$ gaat brengen, valt

132. Kamerstukken II $2014 / 2015,34138,4$, p. 3.

133. Zie bijv. HR 12 juli 2013, ECLI:NL:HR:2013:BZ9959, JBPr 2013/53 m.nt. Steneker, NJ 2014/273 m.nt. Van Mierlo; in de Agenda voor de Appelrechtspraak 2020 is aanbevolen om hiervoor de appelgrens als maatstaf te hanteren.

134. Vgl. HR 28 november 1986, ECLI:NL:HR:1986:AC9604, NJ $1987 / 380$.

135. Asser/Bakels, Hammerstein \& Wesseling-van Gent 4 2012/250; anders: Hof Den Bosch 6 mei 2014, ECLI:NL:GHSHE:2014:1287, JBPr 2014/43 m.nt. Sluijter.

136. HR 19 september 2014, ECLI:NL:HR:2014:2739.

137. Vgl. Snijders/Wendels 2009/228.

138. Conclusie A-G Wissink voor HR 24 januari 2014, ECLI:NL:PHR: 2013:1835.

139. HR 1 maart 2013, ECLI:NL:HR:2013:BY6760; zie eerder in deze zin HR 28 oktober 2011, ECLI:NL:HR:2011:BQ6079, NJ 2012/213. 
buiten de scope van deze kroniek. ${ }^{140}$ Los van de digitalisering en de knelpunten die dat met zich gaat brengen, ${ }^{141}$ lijken de veranderingen voor het procesrecht in hoger beroep niet al te groot. Ik noem de volgende punten. Uitgangspunt wordt het langs elektronische weg aanbrengen van procedures en indienen en inzien van stukken tijdens de procedure. Nieuw is ook dat er in hoger beroep één inleidend document zal zijn, wat 'procesinleiding' (art. 343 Rv-nieuw) moet gaan heten; hiermee kan gezamenlijk hoger beroep worden ingesteld van vonnissen en beschikkingen. De appeltermijn verandert niet. De termijnen om in de procedure te verschijnen, om de gronden van het hoger beroep in te dienen en om verweer te voeren worden in de wet vastgelegd. Er komt een wettelijke termijn voor het doen van uitspraak door de appelrechter (tien weken in vorderingsprocedures, zes weken in kort geding en zes weken in verzoekprocedures). De onmogelijkheid om voor het eerst in hoger beroep een partij in vrijwaring op te roepen wordt in de wet vastgelegd. ${ }^{142} \mathrm{Ik}$ noemde al de afschaffing van het pleidooi en de nadruk op de mondelinge behandeling. De comparitie na aanbrengen is niet gecodificeerd, maar in de toelichting is wel benadrukt dat deze mogelijk blijft. De tweeconclusieregel, op grond waarvan in hoger beroep een beperkte stukkenwisseling plaatsvindt, wordt niet gewijzigd. Ook in het grievenstelsel en de devolutieve werking brengt het voorstel geen verandering. Volgens de toelichting moet over een mogelijke aanpassing daarvan nog nadere discussie plaatsvinden. De oproep om aan deze discussie bij te dragen, heeft inmiddels van verschillende kanten geklonken. ${ }^{143}$

Mr. drs. F.J.P. Lock

140. Zie in dit verband ook de bijdrage van Teuben en Jansen elders in dit nummer.

141. Zie H.W. Wefers Bettink, Digitalisering van de civiele procedure: gevolgen voor de procespraktijk, TCR 2015, afl. 1, p. 1-6.

142. Herstel van een eerdere omissie van de wetgever en codificatie van $H R$ 14 december 2007, ECLI:NL:HR:2007:BB7189, NJ 2008/9.

143. Zie W.D.H. Asser, Deconstructie van grievenstelsel/devolutieve werking, TCR 2014, afl. 4, p. 101-102, Redactioneel, TCR 2014, afl. 3, p. 65 en Ernste 2015.

\section{Familieprocesrecht}

Het is alweer geruime tijd geleden dat er een kroniek over het familieprocesrecht is verschenen. Dit brengt mij ertoe om de belangrijkste jurisprudentie van de Hoge Raad vanaf halverwege 2012 kort langs te gaan.

Aan de orde komen het begrip belanghebbende (art. 798 van het Wetboek van Burgerlijke Rechtsvordering, Rv) in kinderbeschermingsmaatregelen en zaken van onderbewindstelling alsmede de processuele positie van de minderjarige en daarmee samenhangend het recht van de minderjarige op inzage van processtukken. Vervolgens komen aan de orde het verweerschrift, het grievenstelsel en de provisionele voorziening. Afgesloten wordt met de oproeping voor de mondelinge behandeling, gezag van gewijsde en de contra-expertise.

Ik zal beginnen met kort aandacht te besteden aan de aanpassing van een aantal artikelen uit het $\mathrm{Rv}$ in verband met de herziening van de maatregelen van kinderbescherming.

\section{Wetgeving}

In het kader van de herziening van de maatregelen van kinderbescherming die in werking is getreden op 1 januari 2015, is art. $798 \mathrm{Rv}$ aangepast. Als belanghebbende wordt tevens beschouwd degene die niet de ouder is en de minderjarige op wie de zaak betrekking heeft gedurende ten minste één jaar als behorende tot zijn gezin verzorgt en opvoedt. Achtergrond hiervan is versteviging van de positie van de pleegouders in kinderbeschermingszaken.

Uit de wetsgeschiedenis ${ }^{1}$ blijkt dat de bedoeling van deze toevoeging is om in gevallen waarin kinderen in een perspectiefbiedend pleeggezin (pleegouders zorgen ten minste al één jaar voor het kind) verblijven, de pleegouders in staat te stellen het woord te voeren en hun zienswijze weer te geven.

In dat geval had het meer voor de hand gelegen art. 800 lid $2 \mathrm{Rv}$ aan te scherpen met een toevoeging in verband met de positie van de pleegouders. ${ }^{2} \mathrm{Nu}$ is aan de pleegouders in het algemeen een processuele positie als belanghebbende gegeven en dat betekent dat zij ook bijvoorbeeld in alimentatieprocedures met betrekking tot het pleegkind, die in essentie tussen de ouders gevoerd worden, als belanghebbende moeten worden opgeroepen. Neemt men de toevoeging in art. $798 \mathrm{Rv}$ in letterlijke zin, dan zou ook de samenwonende maar nietgehuwde of geregistreerde partner van de moeder als belanghebbende aangemerkt moeten worden in een alimentatiezaak die gevoerd wordt tussen de ouders van het kind, terwijl deze partner geen alimentatieverplichting ten opzichte van het kind van zijn partner heeft. ${ }^{3}$ Waar men de pleegouders daadwerkelijk een processuele positie als verzoeker of belanghebbende wil geven, ligt het meer voor de hand dat in de specifieke materiële wetgeving op te nemen.

1. Kamerstukken II 2013/14, 32015, 37, amendement Kooiman en Van Tooren.

2. Zie ook Wortmann in haar noot onder HR 12 september 2014, NJ $2014 / 482$.

3. Overigens zijn er uitspraken om een dergelijk verschil met de stiefvader niet langer meer te maken. 